\title{
CHOICE OF LAW AND THE PROPOSED FEDERAL RULES OF EVIDENCE: NEW PERSPECTIVES*
}

\author{
LOUISE WEINBERG $\dagger$
}

\section{Introduction: The Problem before Congress}

On November 20, 1972, the Supreme Court promulgated a new federal evidentiary code, ${ }^{1}$ to become effective July 1,1973 , unless Congress took supervening action. ${ }^{2}$ It was then for Congress to determine, if only by inaction, whether the proposed Federal Rules of Evidence would control trials of cases in federal courts. It was widely anticipated that Congress would, as a matter of course, allow the proposed rules to take effcct. ${ }^{3}$ However, despite the submission to the profession of substantially similar preliminary drafts in $1969^{4}$ and in 1971,5 the proposed rules have recently become the focus of criticism. The controversy centers for the most part upon two issues: first, whether procedural evidentiary rules have been used to effect substantive changes in the law; and second, whether the new rules override conflicting state rules thought to be substantive in nature in cases in which state law supplies the rule of decision. ${ }^{6}$ In response to this controversy Congress has passed a bill postponing the rules'

* The author wishes to express appreciation for many valuable insights to Professor Donald T. Trautman of the Harvard Law School.

$\dagger$ Teaching Fellow, Harvard Law School. A.B. 1954, Cornell University; J.D. 1969, Harvard University. Member, Massachusetts Bar.

1 Rules of Evidence for United States Courts and Magistrates, 56 F.R.D. 183 (1972) [hereinafter cited as Proposed Fed. R. Evid.]. The historical background of the proposed rules has been fully detailed elsewhere. A good account may be found in Spangenberg, The Federal Rules of Evidence-An Attempt at Uniformity in Federal Courts, 15 WAYNE L. REV. 1061 (1969) (Mr. Spangenberg is a member of the Advisory Committee on Rules of Evidence, Judicial Conference of the United States). Background also appears in Hearings on Proposed Rules of Evidence Before the Special Subcomm. on Reform of Federal Criminal Laws of the House Comm. on the Judiciary, 93d Cong., 1st Sess. ser. 2, at 11 (1973) (testimony of Judge Albert B. Maris, Chairman, Standing Committee on Rules of Practice and Procedure, Judicial Conference of the United States; Albert E. Jenner, Jr., Chairman, Advisory Committee on Rules of Evidence, Judicial Conference of the United States; Professor Edward W. Cleary, Reporter, Advisory Committee on Rules of Evidence, Judicial Conference of the United States) [hereinafter cited as Hearings].

${ }_{2}^{2}$ See 18 U.S.C. \& 3771 (1970); 28 U.S.C. $\$ 2072$ (1970).

${ }^{3}$ See, e.g., Mackenzie, New Rules of Evidence, U.S. Courts Facing Changes, Washington Post, Nov. 24, 1972, at 1 , col. 1 .

${ }_{4}$ Preliminary Draft of Proposed Rules of Evidence for the United States District Courts and Magistrates, 46 F.R.D. 161 (1969).

5 Revised Draft of Proposed Rules of Evidence for the United States Courts and Magistrates, 5I F.R.D. 315 (1971).

${ }_{6}$ Weaver, Court Rule Shift Opposed in House, Panel Votes Indefinite Delay in Evidence Changes, N.Y. Times, March 7, 1973, at 25, col. 1. 
effective date until such time as. Congress should affirmatively approve them; ${ }^{7}$ and on March 30, 1973, this legislation was signed into law by President Nixon. ${ }^{8}$

This Article does not directly deal with either of the issues just mentioned. Rather, it focuses on functional choice-of-law considerations bearing upon promulgation of federal evidentiary rules. These considerations are peculiarly for the Congress to weigh in examining the proposed rules, because they concern the wisdom of promulgating the proposed rules as a unit and cannot be expected to arise by way of litigation on a case-by-case basis, as challenges to the validity of particular rules might arise.

Section II, following, argues that although there is no constitutional impediment to promulgation of federal evidentiary rules within the reach of Erie Railroad Co. $v$. Tompkins, ${ }^{9}$ there are important desiderata beyond the scope of Erie which have their source in fundamental understandings of the appropriate uses of federal law in our federal system and which may, in the absence of clearly countervailing national needs, require the application of state law even to procedural issues. Section III explores arguments generally advanced in favor of uniform federal evidentiary rules in federal courts. This leads to conclusions, first that although there is a genuine need to unify the reception of evidence in federal courts under all heads of federal jurisdiction, it is not necessary that a comprehensive code of federal evidentiary law be created to deal with the problem; and second that arguments favoring adoption of the proposed rules based on the national interest in evidentiary reform must fail by virtue of the failure of the proposed rules to effect reform. In this latter respect the Federal Rules of Civil Procedure are distinguished from the proposed Federal Rules of Evidence. Section IV examines functional considerations favoring federal conformity to state law in procedural matters generally and in evidentiary matters particularly. In Section V, segments of the proposed rules are critically scrutinized in light of considerations raised in Section IV, and it is argued that new federal evidentiary law on the scale proposed would create substantial

${ }^{7}$ The proposed rules were sent to the Subcommittee on Criminal Justice (then the Special Committee on Reform of Federal Criminal Laws) of the House Judiciary Committee for hearings in February and March of 1973. In June of 1973, the subcommittee published a proposed bill which would establish the rules with numerous amendments. H.R. 5463, 93d Cong., 1st Sess., reprinted in 42 U.S.L.W. 1 (1973). The bill was reported out of the subcommittee with amendments on November 15, 1973. H.R. REP. No. 650, 93d Cong., Ist Sess. (1973). The bill passed the House Feb. 6. 1974. 120 CoNG. REC. H570 (1974) and is presently before the Senate.

8 Act of Mar. 30, 1973, Pub. L. No. 93-12, 87 Stat. 9.

9304 U.S. 64 (1938). 
difficulties for lawyers in both state and federal courts. Section VI then proposes a federal legislative choice-of-law rule as a superior technique for dealing with existing evidentiary problems in federal courts.

\section{Toward a More Meaningful Analysis of Procedural Choice-of-Law Questions for Federal Courts}

Customary analysis of the proposed Federal Rules of Evidence has proceeded in two stages. First, after reassuring themselves that the proposed rules were within the Supreme Court's power to promulgate under the enabling legislation, ${ }^{10}$ the Advisory Committee ${ }^{11}$ and the commentators ${ }^{12}$ have inquired into the proposed rules' constitutionality under the principles of Erie. The Erie analysis focuses upon the validity of particular rules ${ }^{13}$ rather than the rules as a whole, because evidentiary rules are generally characterized as procedural. ${ }^{14}$ Only the more "substantive" in content of the proposed rules are thought to present any real constitutional difficulty, and then only in cases as to which state law supplies the rule of decision (chiefly diversity cases). Thus, the draftsmen of the proposed rules, sensitive to Erie, have mandated reference to state law for rules governing certain presumptions in trials of civil cases where state law supplies the rule of decision. ${ }^{15}$ Similarly, an exclusive code of federal privileges has been created, ${ }^{16}$ but only after consideration of the constitutional question. ${ }^{17}$

${ }^{10} 18$ U.S.C. $\$ 3771$ (1970) (criminal); 28 U.S.C. $\$ 2072$ (1970); id. § 2075 (bankruptcy). See Committee on Rules of Practice and Procedure of the Judicial Conference of the United States, A Preliminary Report on the Advisability and Feasibility of Developing Uniform Rules of Evidence for the United States District Courts, 30 F.R.D. 73, 100-05 (1962) [hereinafter cited as 1962 Preliminary Report]; authorities cited in Weinstein, The Uniformity-Conformity Dilemma Facing Draftsmen of Federal Rules of Evidence, 69 Colum. L. REV. 353, 355 n.12 (1969). Significantly, however, H.R. REP. No. 650, 93d Cong., lst Sess. 2 (1973), concludes that the Supreme Court lacked power under the enabling acts to promulgate the proposed rules.

11 See 1962 Preliminary Report, supra note 10, at 105-08.

12 See Degnan, The Law of Federal Evidence Reform, 76 HARv. L. Rev. 275, 287-301 (1962); Green, Highlights of the Proposed Federal Rules of Evidence, 4 GA. L. REv. I, 14 (1969); Ladd, Uniform Evidence Rules in the Federal Courts, 49 VA. L. REv. 292 (1963); Weinstein, supra note 10, at 356-57. See also Wright, Procedural Reform: Its Limitations and Its Future, 1 GA. L. REv. 563, 571-72 (1967).

${ }_{13}^{13}$ See e.g., Proposed Fed. R. Evid. 302, Advisory Comm. Note, 56 F.R.D. 211 ; id. Rule 901, Advisory Comm. Note, 56 F.R.D. 230.

${ }^{14}$ See 1962 Preliminary Report, supra note 10, at 108: "The generally accepted view ...; is that most evidence rules are merely procedural and not within the Erie doctrine." (footnote omitted). See also authorities cited note 12 supra.

${ }_{15}$ Proposed Fed. R. Evid. 302, 56 F.R.D. 211.

${ }^{16}$ Id. Rules 501-12, 56 F.R.D. 230-59.

${ }^{17}$ See Proposed Fed. R. Evid. 501, Advisory Comm. Note, 56 F.R.D. 230-34. The House bill would apply state privileges in civil cases for which state law supplies the rule of decision, H.R. 5463, 93d Cong., 1st Sess. rule 302, reprinted in 42 U.S.L.W. 5 (1973), and would eliminate the code of federal privileges. However, the bill would permit federal courts to work out a federal common law of privileges in federal law cases. H.R. 5463, 93d Cong., 1st Sess. rule 501, reprinted in 42 U.S.L.W. 6 (1973). 
The narrow constitutional question under Erie is further narrowed, perhaps beyond the point of usefulness, by the decision in Hanna $v$. Plumer. ${ }^{18}$ Hanna is widely understood-and understood by the rules' draftsmen ${ }^{19}$ - to mean that Congress and its rulemaking delegate have legislative competence, with respect to any question rationally classifiable as "procedural," to make rules for federal courts which will override a directly conflicting state rule even in state law cases. The appropriateness of the exercise of that power, however, is a question that does not arise under Erie and Hanna.

Given the sweeping applicability of an arguably procedural rule after Hanna, a second consideration has drawn increased attention in the commentators' analyses. ${ }^{20}$ As expressed by the American Bar Association Special Committee on Federal Rules of Procedure,

Rulemakers must ... weigh, in much the same way as Congress might, the desirability of uniformity and efficiency in federal litigation against the desirability of permitting the states, wherever possible, to exercise power and enforce their own policy in areas normally regulated by the states. ${ }^{21}$

The concern expressed by these commentators is not radically different from that underlying Erie: to avoid displacement of substantive state law by federal rules in situations where arguably "substantive" state interests should control. Thus, "writers have suggested that, even if the Supreme Court can legally issue Federal Rules of Evidence which conflict with state policy in areas which are properly the concern of the states, it should not do so." ${ }^{2}$ Like the Erie issue, this policy problem focuses on individual rules and their applications.

But of course there has always existed a prior question, which in the early stages was appropriately for the Advisory Committee and now, clearly, is for Congress: ${ }^{23}$ whether

18380 U.S. 460 (1965).

${ }^{19}$ See Proposed Fed. R. Evid. 501, Advisory Comm. Note, 56 F.R.D. 32-33, citing Wright, supra note 12, at 572-73. "Regardless of what once might have been thought to be the command of Erie R.R. v. Tompkins ... Hanna v. Plumer ... is believed to locate the problem in the area of choice ...."

${ }^{20}$ See Cleary, The Plan for the Adoption of Rules of Evidence for United States Districo Courts, 25 Rec. Ass'N BAR of CrrY of N.Y. 142, 145 (1970); Green, supra note 12, at 6-17; Weinstein, supra note 10, at 357-61; Wright, supra note 12, at 572-74.

2138 F.R.D. 95, 103 (1965). The Committee was considering amendments to Federal Rule of Civil Procedure 23 in its report, but the principle is appropriately applied to evidence rules as well. See Green, supra note 12, at 7; Weinstein, suppra note 10, at 357-58.

${ }^{22}$ Green, supra note 12, at 6 (footnote omitted) (citing Degnan, supra note 12; Weinstein, supra note 10; Wright, supra note 12). litigation.

${ }^{23}$ Unlike Erie questions, this basic issue cannot be expected to arise by way of 
-assuming Congress has the power-to promulgate a code of new federal rules at all. The answer to this question cannot, of course, be furnished by Erie or Hanna or by separate examination of the policies affected by particular rules. It requires a weighing of broader functional considerations in light of the needs of our dual court system, and with sensitivity to the nature and uses of federal law in that system.

This prior question was ignored by the Advisory Committee, however, ${ }^{24}$ and has received only cursory treatment in the literature, ${ }^{25}$ a result no doubt partly attributable to the fact that its answer seems to have been presumed all along. ${ }^{26} \mathrm{~A}$ virtual presumption in favor of federal law for federal procedure has pervaded the discussion with a surface reasonableness that has made further analysis appear unnecessary or even reactionary. We find ourselves at the crest of the historic wave of enthusiastic reform of federal procedure that for generations has swept all objections before it, and is made almost irresistible by the success of the Federal Rules of Civil Procedure. ${ }^{27}$ Yet it is at least possible to distinguish evidentiary rules from procedural rules generally, as Section IV, below, attempts to do, and quite possible to distinguish the proposed Federal Rules of Evidence from the Federal Rules of Civil Procedure, as is attempted in Section III. Moreover, our thinking about the role of federal law in our federal system has undergone great changes since the inception of the movement that led to the Federal Rules of Civil Procedure. A fresh look at the propriety of federal law for this area might be helpful. ${ }^{28}$

${ }^{24}$ See Hearings, supra note 1, at 246 (testimony of Judge Henry Friendly):

With the benefit of hindsight, the error seems to me to have lain in the too ready acceptance, without opportunity for any full debate of the preliminary report many years ago that Federal Rules of Evidence should be drafted. It was natural that there was not much debate. After all, the proposal was simply that a committee be appointed to attempt to draft rules. . . . Once the Advisory Committee on Rules of Evidence ... went to work, the project acquired its own momentum. The questions that were put to the profession when the drafted rules were circulated were not whether there should be such rules-an issue that apparently was regarded as having been settled-but what the rules should be.

${ }_{25}$ See Callahan \& Ferguson, Evidence and the New Federal Rules of Civil Procedure, 45 YALE G.J. 622, 644-47 (1936); Weinstein, supra note 10, at 358-61. Weinstein, who has given the issue its fullest consideration, states without citation to example or authority that "Almost every commentator who has considered the matter favors adoption of a comprehensive set of federal rules of evidence." Id. 355. After a brief discussion, he concludes that the only real problems revolve around particular rules of substantive impact. Id. 361.

${ }^{26}$ See note 24 supra.

27 See Section III infra.

${ }^{28} \mathrm{~A}$ related reason for the generally prevailing assumption that the proposed federal evidence code would be an appropriate exercise of national lawmaking power may have been a tendency to rely upon the notion, long a maxim of conflicts law, that procedure is for the forum. See Restatement (SECOND) OF Conflicts of Laws $\$ 122$ (1971) [hereinaf- 
This is not to argue that it would be merely desirable or convenient to consider the advantages and disadvantages of the proposed new rules. Rather, such scrutiny is virtually required by a principle of serious institutional dignity, the principle of restraint in the exercise of national lawmaking power. This principle requires as a precondition of the exercise of national lawmaking power a clear showing of national need. ${ }^{29}$ In addition this principle requires that even where a national need has been clearly shown, national lawmaking power must be exercised in the manner least intrusive upon local needs. Thus, as has been observed by weighty authority, federal law in our system has traditionally been and continues to be interstitial. ${ }^{\mathbf{3 0}}$ The mass of power to regulate the ordinary affairs of citizens is allocated to the states; and federal law, statutory or decisional, arises to meet national needs only as those needs arise.

This restraint in the exercise of federal lawmaking power rests on important national policies. These include the interest in economy of federal lawmaking effort. ${ }^{31}$ But they also encompass more important interests, the interest in the smooth functioning of the federal system, which in turn depends on avoiding interference with state policy concerns and disruption of settled local arrangements and expectations. These are national rather than state policy concerns. Finally, the principle of restraint in the exercise of federal lawmaking power rests on the national interest in avoiding, where possible, duplicate sets of laws governing similar conduct, with the attendant risks of undue complexity $^{32}$ and of unseemly, disturbing or unfair disparities.

ter cited as REsTATEMENT]. But it should be pointed out that this maxim does not apply where a federal-state (vertical) choice-of-law problem is presented. See id. Introductory Note to Ch. 6 (procedural chapter inapplicable to vertical conflicts of laws). Unlike the courts of any state, a federal trial court is located within a separate jurisdictional entity already employing local procedures. While it would be unreasonable ever to impose upon one state's courts the burden of applying another state's merely procedural laws, all trial lawyers and many trial judges in the federal courts, being members of the bar of the state in which the federal district court sits, are already fully familiar with the procedural rules of the courts of that state. In this light, then, it is clear that the maxim properly signifies that procedure is for the forum state.

${ }^{29}$ See, e.g., United Auto Workers v. Hoosier Cardinal Corp., 383 U.S. 696 (1966) (timeliness of suits for breach of contract under $\S 301$ of the Labor-Management Relations Act determined by state law, in view of federal statutory silence on the issue, where no predominant federal interest in uniformity was established); Degnan, supra note 12, at 301: "the federal government should not undertake to correct state errors except when protecting a vital federal interest." See generally Comment, The Federal Common Law, 82 HARv. L. REv. 1512 (1969) (arguing for a presumption in favor of state law). (1953).

${ }^{30}$ H. Hart \& H. Wechsler, The Federal Courts And The Federal System 435

${ }^{31}$ See, e.g., Royal Indemnity Co. v. United States, 313 U.S. 289 (1941) (state rate applied in determining interest on federal judgment).

${ }^{32}$ See generally A. Von Mehren \& D. Trautman, The Law Of Multistate Problems 
These latter concerns, of course, underlie the mandate of Erie, in the sense that disregard of them may produce federal law so clearly inappropriate as to be unconstitutional. ${ }^{33}$

Thus, only a preliminary showing of national need can justify an exercise of national lawmaking power, and then only upon a preliminary determination that such need is sufficient to override these preexisting national policies. Finally, even where an overriding need has been shown, national policy requires that federal lawmaking power be exercised only with restraint, that is, in the least intrusive way capable of satisfying the national need. The inquiry into the nature of the national need, its weight and the least intrusive ways of satisfying it will compel scrutiny of the functional advantages and disadvantages of the alternatives.

While the question whether to have a federal evidentiary code now arises in the legislative context, the principle of restraint in the exercise of national lawmaking power has been most systematically articulated in the context of judicial decisions. In fleshing out a federal statutory framework, the courts have considered whether to interpolate federal law where the statutes are silent or whether to apply established state law. The Supreme Court has frequently ${ }^{34}$ held that where there is no demonstrable national need to the contrary, existing state law, rather than new federal law, was to be used. ${ }^{35}$ For example, the Court has adopted state rules to supplement substantive federal law in cases arising under federal law, whether within ${ }^{36}$ or withou $\mathrm{t}^{37}$ the diversity jurisdiction. With respect to procedure, in

1049-59 (1965) [hereinafter cited as VON MEHREN \& TRAUTMAN]; examples cited notes 35-44 infra.

${ }^{33}$ See Erie R.R. v. Tompkins, 304 U.S. 64, 74-78 (1938); $c f$. Hanna v. Plumer, 380 U.S. 460, 474-75 (1965) (Harlan, J., concurring).

${ }^{34}$ But cf., e.g., Textile Workers Union v. Lincoln Mills, 353 U.S. 448 (1957) (federal common law to supply substantive law in actions under $\S 301$ of the Labor-Management Relations Act).

${ }^{35}$ Federal law tends to rely for the very meaning of words and concepts on state law understandings. "For example, federal tax legislation uses such terms as 'sale,' 'wife,' 'husband, and 'gift.' These concepts are often not regulated by any federal rules, legislative or judicial; instead, state law is drawn on to supplement the federal rule and thus provide a fully dispositive rule." Von MEHren \& TraUTMAN, supra note 32, at 1050. See, e.g., De Sylva v. Ballentine, 351 U.S. 570 (1956) (state law governs who is a "child" for purposes of copyright renewal). But see Weber v. Aetna Cas. \& Sur. Co., 406 U.S. 164 (1972) (recognition of national constitutional limit on state power to discriminate against illegitimate children). See generally D'Oench, Duhme \& Co. v. F.D.I.C., 315 U.S. 447, 465 (1942) (Jackson, J., concurring).

${ }^{36}$ See, e.g., Bank of America National Trust \& Savings Ass'n v. Parnell, 352 U.S. 29 (1956) (state law held to govern burden of proof in diversity case on issue of good faith of taker of government bonds, no federal need for special rule, but federal law governs issue of whether bonds are overdue).

${ }^{37}$ See, e.g., Yiatchos v. Yiatchos, 376 U.S. 306 (1964) (survival provisions of government bonds modified by state community property laws, to avoid unfair change in settled property law); United States v. Brosnan, 363 U.S. 237 (1960) (federal tax liens extin- 
cases within the diversity jurisdiction the Court has applied state law to numerous issues rationally capable of classification as "procedural." ${ }^{38}$ Arguably, Hanna v. Plumer may be read for the proposition that state law is presumed to control federal procedure in state law cases absent clearly conflicting federal authority. ${ }^{39}$ Indeed, state law has been held to govern certain "procedural" points even in federal question cases, ${ }^{40}$ where no need for an independent uniform national rule can be made out. ${ }^{41}$ These decisions would seem to demonstrate a presumption in favor of state procedural law for trials under all headings of federal jurisdiction, and not a presumption in favor of federal procedural law.

That Congress has characteristically restrained its legislative power, absent the showing of a clear national need, may be fairly argued. But the point may be more simply made by noting the frequent congressional use of mandatory reference to state law to furnish the content of federal laws. ${ }^{42}$ The example most clearly related to this discussion, of course, is the long history of congressionally required conformity of federal court procedures to state procedural law. ${ }^{43}$ This pattern of conformity was not

guished by prior state foreclosure proceedings to which the United States was not a party, to avoid intrusion upon expectations under settled property law); De Sylva v. Ballentine, 351 U.S. 570 (1956) (state law governs who is a "child" for purposes of copyright renewal); Reconstruction Finance Corp. v. Beaver County, 328 U.S. 204 (1946) (state law controls whether machinery is real or personal property for tax purposes under Reconstruction Finance Corporation Act, to avoid raising undue disparities in absence of need for uniform rule; state law here apparently used to give content to federal law); $R$. Weintraub, Commentary on the Conflict of Laws 465 n.l (1971).

${ }^{38}$ See, e.g., Guaranty Trust Co. v. York, 326 U.S. 99 (1945) (statute of limitations); Bernhardt v. Polygraphic Co. of America, 350 U.S. 198 (1953) (irrevocable arbitration clause); Cohen v. Beneficial Industrial Loan Corp., 337 U.S. 541 (1949) (security for expenses in stockholder derivative action).

${ }_{39}$ See 380 U.S. at 470,472 . Some lower courts continue to apply state law on a pre-Hanna approach despite apparent applicability of the Federal Rules of Civil Procedure when the issue is arguably procedural. Comment, Uneasiness In The Lower Federal Courts Over Federal Rules Supremacy, 64 Nw. U.L. Rev. 207, 223-27 (1969).

${ }^{40}$ See, e.g., United Auto Workers v. Hoosier Cardinal Corp., 383 U.S. 696 (1966) (period of limitations for actions under $\S 301$ of the Labor-Management Relations Act); Royal Indemnity Co. v. United States, 313 U.S. 289 (1941) (interest rate applied on federal judgment).

${ }^{41}$ Where there is such a national need, it may govern at the trial of federal questions even in state courts. E.g., Dice v. Akron, Canton \& Youngstown R.R., 342 U.S. 359 (1952) (state court required to permit trial by jury of fraud issue concerning validity of release in F.E.L.A. case).

${ }^{42}$ See, e.g., Reconstruction Finance Corporation Act, 15 U.S.C. § 607 (1970); Assimilative Claims Act, 18 id. $\$ 13$; Federal Tort Claims Act, 28 id. \& 2674; FED. R. Crv. P. $4(\mathrm{e}), 17(\mathrm{~b}), 62(\mathrm{f}), 64,69(\mathrm{a}) ; c f$. cases cited notes $35,37,40$ supra.

${ }_{43}$ Act of Sept. 29, 1789, ch. 21, \& 2, 1 Stat. 93; Act of May 8, 1792, ch. 36, 1 Stat. 275; Act of May 19, 1828, ch. 68, 4 Stat. 278; Act of Aug. 1, 1842, ch. 109, 5 Stat. 499; Act of June 1, 1872, ch. 255, $\S 5,6,17$ Stat. 196, 197 ( 5 prescribing "that the practice, pleadings, and forms and modes of proceeding in other than equity and admiralty causes in the circuit and district courts .... shall conform, as near as may be, to the practice ... existing at the time in like causes in the courts of record of the State within which such circuit or district courts are held, any rule of court to the contrary notwithstanding...." 
altered until the promulgation in 1938 of separate federal rules of civil procedure which constituted a very significant improvement over the confused system of conformity then existing ${ }^{44}$ and furthered a national interest in procedural reform in all courts by serving as a model for the states.

In light of the important limitations upon the use of federal law apart from Erie, then, it is clear that the questions for Congress cannot be limited to the remote issue whether there is national lawmaking power or to the question whether particular rules will have a substantive impact on state policies. ${ }^{45}$ Rather, the questions for Congress are: What, as a functional matter, are the present problems associated with the reception of evidence in federal courts? What other national needs in this area can be identified? Would the promulgation of uniform national evidentiary rules for federal courts satisfy such national problems and needs? Specifically, would the promulgation of the proposed rules do so? Would the proposed rules intrude in an undesirable way upon the preexisting background of state evidentiary law? If so, are there less intrusive alternatives than the promulgation of the proposed rules or of any uniform national evidentiary rules, alternatives which could solve genuine evidentiary problems currently obtaining in federal courts?

\section{Advantages of Uniform Federal Rules of Evidence: Federal Rules of Givil Procedure Distinguished}

\section{A. Uniformity Throughout Federal Courts}

Of the commentators who argue the need for uniformity in federal evidentiary rules throughout the federal court system, Judge Weinstein has stated the position most cogently:

$[\mathrm{L}]$ ooked at from the vantage point of Washington, the pressure towards uniform rules of evidence in the federal courts is great. It would make it easier to move

44 Prior to 1872 the conformity mandated by statute was a static conformity to state procedures existing at the time of the enactment of the federal statute. But these procedures were rendered obsolete by the 19th century code-pleading reforms; the reforms were thus eroding whatever convenient conformity in procedure had obtained thitherto. The Conformity Act of 1872 substituted a continuing for a static conformity. The Conformity Act was, however, merely the statement of a general rule, subject to important exceptions, the most destructive of which were the Act's inapplicability in equity and in criminal cases. See Clark, A New Federal Procedure, Procedure: The HANDMAID OF JUSTICE 8 (C.A. Wright \& H. Reasoner eds. 1960). C.A. WRIGHT, Law of FEDeral Courts $\S 61$ (2d ed. 1970).

${ }_{45}$ The House Committee, thinking to avoid impingement on local policy concerns through rule-by-rule reference (where it thought necessary) to state law in H.R. 5463, has remained insensitive to this point, however. 
judges from state to state to meet temporary litigation pressures and thus would accommodate the strong administrative tendency towards a more integrated and efficient federal judicial system. It gives recognition to a growing national bar practicing in the federal courts and the desirability of making it easier for both lawyers and their national clients to find an equal grade of justice administered by familiar procedure in any federal court in the country. Where federal substantive policies are being enforced, a more uniform policy is fairer and more predictable and is likely to strengthen and bind the nation together. ${ }^{46}$

But it is puzzling to find that Judge Weinstein regards these arguments as convincing. First, those utilizing the rules will be trial lawyers engaged in predominantly local practice, ${ }^{47}$ whose need, as Judge Weinstein recognizes, will be for uniformity between local and federal procedures, not interstate uniformity. ${ }^{48}$ State evidentiary law is what all lawyers have had to learn in preparation for state bar examinations and state court practice. Although a few interstate agreements allow the lawyers of one state to practice in another, it remains the general experience that trial lawyers are reluctant to accept out-of-state cases. Even where a state court admits out-of-state lawyers to practice pro hac vice, an out-of-state lawyer is considered, and probably considers himself, to be at a disadvantage, chiefly for intangible reasons having as much to do with local prejudices as with local procedural variations. It is fair to say that the preferred technique, for lawyers with "national clients" (to use Judge Weinstein's phrase) as for others, is to obtain by referral ${ }^{49}$ counsel experienced in the courts where a case is to be tried. 98.

${ }^{46}$ Weinstein, supra note 10, at 359. See also 1962 Preliminary Report, supra note 10, at

${ }^{47}$ Cf. Leach, State Law of Evidence in Federal Courts, 43 Harv. L. Rev. 554, 584 (1930):

It has been suggested that [application of state evidence law] puts too great a burden on federal judges who must sit in several jurisdictions and who must therefore become familiar with several varying systems of state law. ... But ... the hardship on the federal judge is no greater than the hardship placed on the bar by an absence of conformity, and is probably less in view of the fact that counsel have the duty of informing the court on matters peculiar to their state law.

${ }^{48}$ See Weinstein, supra note 10 , at 358 ; Hearings, supra note 1 , at 481 (testimony of Sturart H. Johnson), 200, 202-03, 210 (testimony of George A. Spiegelberg, American College of Trial Lawyers), 209 (testimony of Robert L. Cgare, Jr., New York Trial Lawyers Committee), 168, 170 (statement of Charles R. Halpern and George T. Frampton, Jr., Washington Council of Lawyers). See also id. 62 (remarks of Representative William L. Hungate, Chairman, Committee on the Judiciary).

${ }_{49}$ Cavers, Change in Choice-of-Law Thinking and Its Bearing on the Klaxon Problem, in American Law INSTITUTE, STUdY OF THE Division of JURisdiction BeTwEen STATE AND FEDERAL Courts 154, 158 (Tent. Draft No. 1, 1963) (not incorporated into final draft). 
This is especially so since trial of an out-of-state case will entail a lawyer's leaving his family, his practice and the facilities of his office for an open-ended period of time. ${ }^{50}$ Since procedural variations are not an important cause of this pattern, implementation of uniform rules of evidence in federal courts would not seem likely to alter it.

Second, federal trial judges are largely drawn from the bar of the state in which their court sits, and are familiar with state practice. ${ }^{51}$ Judge Weinstein's argument that visiting federal judges ${ }^{52}$ would be assisted by uniformity ${ }^{53}$ cannot be considered compelling in view of the relative infrequency of visits required by genuine emergency. ${ }^{54}$

Finally, Judge Weinstein's argument that federal evidentiary law would make uniform the administration of federal substantive law overlooks the extensive concurrent jurisdiction of federal questions exercised by state courts and their sizable exclusive jurisdiction over numerous federal questions as to which it cannot be alleged that the amount in controversy exceeds $\$ 10,000$. Thus, the arguments that federal courts need interstate uniformity in their evidence rules are at bottom unpersuasive. Although commentators have often called for reform of federal evidentiary practices, the serious problem is not that these practices have not been uniform from state to state. Evidentiary law is criticized generally because it is cumbersome and overrefined. ${ }^{55}$ Federal evidentiary law is criticized in addition because, under the various headings of federal jurisdiction, it has not been clear how or when state law will be applied. ${ }^{56}$ But this

50 These last considerations would seem to make the technique of referral preferable, where circumstances permit, to the technique of arranging for local co-counsel.

${ }^{51}$ See E. Morgan, J. Maguire \& J. Weinstein, Cases on Evidence 258 (4th ed. 1957); Weinstein, supra note 10, at 358. Cf. RESTATEMENT, supra note $28, \S 138$.

${ }^{52}$ See 28 U.S.C. \& 292(d) (Supp. 1973). Based on informal interviews it is the author's understanding that judges consider such sittings to be in the nature of honorific pleasure travel when they take the form of casual exchanges of location, and that there are few occasions when the appointment of a visiting judge is required by the illness or death of another judge.

${ }^{53}$ But of. note 47 supra.

54 See Weinstein, supra note 10 , at 358. But see, e.g., Chicago \& N.W. Ry. v. Kendall, 167 F. 62,70 (1909); Callahan \& Ferguson, supra note 25, at 644; Estes, The Need for Uniform Rules of Evidence in the Federal Courts, 24 F.R.D. 331, 335 (1959), quoting 1962 Preliminary Report, supra note 10, at 111-12.

${ }^{55}$ See J. Thayer, A Preliminary Treatise On Evidence at The Common law, 527-28 (1898); Degnan, supra note 12, at 275-76; Graham, California's "Restatement" of Evidence: Some Reflections On Appellate Repair Of The Codification Fiasco, 4 LovolA U.L.A.L. REV. 279, 287, 307 (1971); Orfield, Uniform Rules Of Evidence, 67 DiCK. L. REv. 381, 382 (1963). Cf. People v. Spriggs, 60 Cal. 2d 868, 389 P.2d 377, 36 Cal. Rptr. 841 (1964).

${ }^{36}$ See 1962 Preliminary Report, supra note 10, at 95-97; Degnan, supra note 12, at 276; Ladd, supra note 12, at 715. Compare Monarch Ins. Co. v. Spach, 281 F.2d 401, 406-09 (5th Cir. 1960), with Allstate Ins. Co. v. Charneski, 286 F.2d 238, 243-44 (7th Cir. 1960). See generally Comment, Rule 43(a) and Erie-The Confict in the Sixth Circuit, 34 TENN. L. Rev. 671 (1971). 
problem is a matter amenable to amelioration by simpler means than adoption of a comprehensive federal evidence code. ${ }^{57}$

\section{B. Unification of Practice Under All Federal Jurisdictional Headings}

There is a genuine, even pressing, need to unify rules governing the reception of evidence among the various headings of federal jurisdiction. ${ }^{58}$ The present evidentiary rules vary depending upon whether the case is civil ${ }^{59}$ or criminal ${ }^{60}$ and, if the former, whether the case is in diversity or under some other heading of federal jurisdiction. ${ }^{61}$ However, unification could be achieved, legislatively or through amendment to the procedural rules, by a simple federal choice-of-law rule requiring conformity to forum-state evidentiary rules for all federal jurisdictional headings, a suggestion further explored in Section VI. Thus, there would seem to be no need for comprehensive new federal evidentiary law to solve the problem.

\section{Effectuation of Federal Jury Policies}

The argument has been made ${ }^{62}$ that rules of evidence in federal courts should be federal rules because control over evidence is one of the important ways a judge controls a jury, and the relation between a federal judge and jury is an area of strong federal concern. ${ }^{63}$ However, this relationship would seem to be protected by the existing body of law addressed to the subject. There is no question, for example, that even if conformity to state evidentiary law were to be legislatively mandated for all headings of federal jurisdiction, a federal judge would con-

57 See text accompanying notes 58-61 infra; Section VI infra.

${ }^{58}$ See authorities cited note 56 supra.

59 See generally, 1962 Preliminary Report, supra note 10 , at 89.

${ }^{60}$ See FED. R. CRIM. P. 26, codifying Funk v. United States, 290 U.S. 371 (1933) (rules of evidence in federal criminal cases to be determined uniformly by federal courts under general common law in light of reason and experience).

61 The practice in federal question cases has been to follow federal decisional law. Independent bodies of federal evidentiary law were developed in bankruptcy and in admiralty prior to the merger of the Bankruptcy Rules with the Federal Rules of Civil Procedure in 1939, General Orders in Bankruptcy 22, 37, 305 U.S. 692, 698 (1939), and the merger of admiralty with civil actions generally in 1966, FED. R. Crv. P. 1. Thereafter it was generally believed that Federal Rule of Civil Procedure 43(a) was applicable in these jurisdictions. In practice, federal question cases have continued to make scant use of state evidentiary law. See Weinstein, supra note 10, at 377 (Sherman Appendix).

${ }^{62}$ See Degnan, supra note 12 , at 292-96.

${ }^{63}$ See U.S. CoNST. amend. VII; Fitzgerald v. United States Lines Co., 374 U.S. 16 (1963); Simler v. Connor, 372 U.S. 221 (1963); Dairy Queen, Inc. v. Wood, 369 U.S. 469 (1962); Beacon Theatres, Inc. v. Westover, 359 U.S. 500 (1958); Byrd v. Blue Ridge Rural Elec. Cooperative, Inc., 356 U.S. 525 (1958); Herron v. Southern Pac. Co., 283 U.S. 91 (1931); FED. R. CIV. P. 38. 
tinue under preexisting, overriding law ${ }^{64}$ to enjoy the freedom to comment upon the evidence, unless it could be shown that it was the intention of the legislature to effect a change in that practice. ${ }^{65}$ Thus, there is no pressing need for the elaboration of a federal code of evidence to protect traditional federal jury arrangements.

\section{Enhancement of the Federal Forum}

The bare provision of a federal forum is thought to effectuate important national interests in the quality and availability of justice. ${ }^{66} \mathrm{It}$ is therefore thought desirable to adopt rules, such as the Federal Rules of Civil Procedure, which may make federal jurisdiction more useful-provide a juster justice. ${ }^{67} \mathrm{~A}$ thoroughly reformed and sophisticated code of evidence, representing the best in current thinking on the subject, would presumably enhance the usefulness and prestige of federal courts. This argument, and the related argument discussed in Subsection E, following, that federal evidence rules would serve as a model for state reform, would have persuasive weight, if their underlying premise were sound: that the proposed rules, as promulgated, represent genuine modernization of the law of evidence.

Undoubtedly the proposed rules represent a sophisticated, scholarly, often wise weighing of the various interests to be accommodated in any evidentiary ruling. But there is little in the rules of evidence now applied in either federal or state courts that is seriously claimed to be foolish or illiberal. ${ }^{68}$ In fact it is

${ }^{64}$ See Capital Traction Co. v. Hof, 174 U.S. 1, 13-16 (1899); Vicksburg \& Meridan R.R. v. Putnam, 118 U.S. 545, 553 (1886); County of Todd v. Loegering, 297 F.2d 470, 480-81 (8th Cir. 1961).

${ }_{65}$ Other rules of evidence, to the "extent that they reflect strong national policy concerns, are also the subject of preexisting overriding constitutional and statutory law. See, e.g., Weeks v. United States, 232 U.S. 383 (1914); 28 U.S.C. \$\$ 1731-45 (1970).

${ }_{66}$ See Szantay v. Beech Aircraft Corp., 349 F.2d 60 (4th Cir. 1965); American Law Institute, STUdY OF THE Division OF JURISDiction Between STate and Federal Courts 4 (1965); Von Menren \& Trautman, supra note 32, at 1009; Friendly, Historic Basis of Diversity Jurisdiction, 4I HARV. L. REV. 483 (1928).

${ }^{67}$ Prior to the drafting of the proposed rules, the most frequently articulated argument in favor of establishing such rules was that of improving the efficiency of the federal courts. See, e.g., 1962 Preliminary Report, supra note 10, at 108-10; Callahan \& Ferguson, supra note 25, at 645-46; Degnan, The Feasibility of Rules of Evidence in Federal Courts, 24 F.R.D. 341 (1960); Estes, supra note 54, at 335, 339; Joiner, Uniform Rules of Evidence for the Federal Courts, 20 F.R.D. 429, 440 (1957); Orfield, supra note 55, at 381-83. Professor Ladd stated: "The promulgation of unified, simplified and improved federal rules of evidence, when completed, can be one of the great contributions of this century to our system of trials." Ladd, supra note 12, at 716. See also Green, supra nooe 12, at 1-2; Weinstein, supra note 10, at 354-55. As the quotation from Professor Ladd illustrates, the arguments for more efficient federal evidence practices do not usually separate the considerations of unification of evidence rules under all heads of federal jurisdiction, text accompanying notes 58-61 supra, and general progress in simplifying the law of evidence itself, the topic of this Subsection.

${ }^{68}$ See Leach, supra note 47, at 583-84 (1930); cf. Weinstein, supra note 10 , at 359. Judge Weinstein argues that the tendency in the state courts to turn to the Uniform 
fair to say that the proposed rules simply take positions with respect to the rules of evidence generally obtaining. ${ }^{69}$ That they may be the best conceivable positions is possible, but what is needed in this context is simplification, not sophistication and refined elaboration. ${ }^{70}$ And simplification is not a feature of the proposed Federal Rules of Evidence. ${ }^{71}$ No proponent of the proposed rules asserts that they are anything other than another detailed, scholarly code. ${ }^{72}$

Indeed, the usefulness of both federal and state courts may well be impaired by enactment of the proposed rules, for they will simply represent another set of rules for local trial lawyers to master. The existence of two such procedural systems side by side, where one does not represent a marked simplification, prima facie will not enhance the usefulness of either set of courts, but at best will create a minor forum-shopping situation and at worst will introduce confusion and doubt into the trial of cases in all courts.

\section{E. Model for Reform of State Rules: Federal Rules of Civil Procedure Distinguished}

This brings us to the argument, often advanced, that new federal evidentiary rules would serve as a model for widespread reform. ${ }^{73}$ It was an unachieved goal of federal policy under Swift v. Tyson ${ }^{74}$ that federal law serve as a model for state law reform. ${ }^{75}$ Arguably, state procedural reform remains a goal of national policy today. There is a national interest in improvement of procedures in all courts because there is a national

Rules of Evidence, the Model Code of Evidence, and other enlightened sources, indicates that the gap between federal and state evidence rules will be slight. Id. 360-61.

${ }^{69}$ See Broun, Authentication and Contents of Writings, 1969 LAW \& Soc. ORDER 611; Green, Relevancy and Its Limits, 1969 LAW \& Soc. ORDER 533. See generally Sections IV, V, infra; Hearings, supra note 1, at 195, 197-99 (letter from Professor Kenneth Graham). The positions taken in various of the proposed rules will of course tend to differ in detail from any particular state rule; see, e.g., Section V infra.

${ }_{70}$ See Section IV infra.

${ }^{71}$ See, e.g., Broun, supra note 69; Davis, Judicial Notice, 1969 LAw \& Soc. ORder 513; Green, supra note 69; Hearings, supra note 1, at 197-98.

${ }^{72}$ See Blackmar, The Proposed Federal Rules of Evidence-How Will They Affect the Trial of Cases, 27 WASH. \& LEE L. REv. 17, 21 (1970); Green, supra, note 12, at 41. Indeed, according to Blackmar, "The proposed rules are often more conservative than the Model Code or the Uniform Rules." Blackmar, supra, at 20. Cf. Green, supra note 69, at 533. See also Hearings, supra note 1, at 17, 24, 25 (testimony of Judge Albert B. Maris, Chairman, Standing Committee on Rules of Practice and Procedure, Judicial Conference of the United States); text accompanying notes 73-108 infra. See generally UNIFORM RULES of Evidence; Model Code of EVIDENCE (1942).

${ }^{73}$ See 1962 Preliminary Report, supra note 10, at 90; Hearings, supra note 1, at 287-88 (statement of Department of Justice); Callahan \& Ferguson, supra note 25, at 646; Joiner, supra note 67, at 439-40; Weinstein, supra note 10 , at 360 ; $c f$. Clark, The Influence of Federal Procedural Reform, 13 LAw \& Contrmp. PROB. 144 (1948).

${ }_{74} 41$ U.S. (16 Pet.) I (1842).

${ }^{75}$ Erie R.R. v. Tompkins, 304 U.S. 64, 74 (1938). 
interest in the sound administration of justice. Moreover, wide state adoption of rules based upon federal rules could contribute importantly to solving the problem of the need of the trial bar for intrastate conformity. The analogy is, of course, to the Federal Rules of Civil Procedure. ${ }^{76}$ As precedent for the Federal Rules of Evidence, the Federal Rules of Civil Procedure, at first blush, may seem so persuasive as to be conclusive. ${ }^{77}$ But there are significant functional differences between the Federal Rules of Civil Procedure and the proposed Rules of Evidence which strongly suggest that the evidence rules would not enjoy nearly the same success in generating reform of state practices.

The Federal Rules of Civil Procedure gave to federal courts great procedural advantages over most state courts; these advantages still exist in states which have not yet enacted substantially the same rules. The draftsmen of the rules did not merely take positions or make choices among the available panoply of procedural rules, from among which any choice might well have been a good one as long as there was some generally accepted procedural framework. Rather, they abolished for federal courts whole classes of distinctions, requirements, limitations. Instead of codifying complex preexisting rules concerning jointness of obligation and sameness of form of action, for example, the federal rule on joinder of actions simply provided that a party may join "as many claims ... as he has against an opposing party."78 The regulatory job previously done by a welter of confusing distinctions was given under rule 42 to the sound discretion of federal judges in shaping a case for trial. Generally state pleading reform had not gone so far. Similarly the federal rules cut off the pleadings at the answer, abolishing pleas and demurrers; ${ }^{\mathbf{7 9}}$ the job of narrowing and sharpening the issues for trial, thitherto accomplished by pleading, was relegated to a handful of discovery devices, and to provisions for motion practice.

This sort of drastic simplification of procedure clearly outweighed the inconvenience to lawyers of learning another set of rules. ${ }^{80}$ Trial lawyers like the Federal Rules of Civil Procedure.

\footnotetext{
${ }^{76}$ Similar rules have been adopted in more than half the states. See Moynihan, Preface, Massachusetts Proposed Rules of Trial and Appellate Procedure (1971).

77 Yet well into this century conformity to state court procedures-although never adequately effectuated-was the goal of federal procedural reform. The history of the various conformity acts reveals the stages in the struggle to reach that goal. See notes 43-44 supra \& accompanying text.

${ }_{78}$ FED. R. GIV. P. 18. See id. Rule 13 (counterclaims).

${ }^{79}$ Id. Rules 7(a), (c); 12.

${ }^{80}$ See Weinstein, supra note 10, at 359: "[T] he federal civil rules provide such a substantial improvement over much state practice that state practice has drifted toward the national pattern."
} 
They appreciate that they do not have to demur or plead in abatement or bar, but may file a catchall answer and do the rest by way of motion. They also appreciate the provisions for counterclaims free of complex rules differentiating set-off and recoupment, ${ }^{81}$ the orderly and powerful discovery procedures, and the availability of liberal devices for joinder of claims. Even the rules for joinder of parties, though still failing to simplify the law to the extent done with respect to joinder of claims, represent a significant improvement over state law. ${ }^{82}$ Under the Federal Rules of Civil Procedure, the freedom with which amendments are permitted virtually eliminates the problems of variance, ${ }^{83}$ and the teeth have been drawn from such formal requirements as the real-party-in-interest rule. ${ }^{84}$ In sum, under the federal rules, parties contemplate a vastly simplified litigational process, involving a brief pleading stage, a busy period of discovery and a hopefully dispositive motion for judgment; thus prepared for settlement, the parties often view trial as unnecessary, indeed, anticlimactic. Such a model has become the norm in our country, and the nineteenth century system now seems aberrational, formalistic, and full of traps.

It would be unduly conclusory to minimize, without a detailed scrutiny beyond the scope of this Article, the achievement that the proposed Federal Rules of Evidence represent. But based on a fair reading of the proposed rules one may conclude that, apart from their scholarly refinement and sophistication, little can be said for them along the lines of the foregoing appraisal of the Federal Rules of Civil Procedure. ${ }^{85}$

Probably the major reason for this difference is that the avowed purpose of the draftsmen of the proposed Federal Rules of Evidence was to limit, rather than to open up, the discretion of a trial judge. ${ }^{86}$ The draftsmen believed that the settlement of cases and the preparation of unsettled cases for trial would be facilitated by detailed rules clarifying from the outset what could and what could not be admitted into evidence.

"1 FED. R. CIv. P. 13.

${ }^{82}$ Id. Rules 19-21 \& accompanying commentary.

${ }^{83}$ Id. Rule 15.

${ }^{84}$ Id. Rules 15, 17.

${ }^{85}$ See generally, Symposium on Proposed Federal Rules of Evidence, 1969 Law \& Soc. ORder 509 .

${ }^{86}$ Spangenberg, supra note 1, at 1061, 1070-71 (1969) (The Advisory Committee made "a major policy decision" not to "state broad general principles" but to make the code "meticulous and detailed"; a major consideration was the fact that "ninety-five percent of civil tort cases are settled without trial," and a "system of evidence rules which would enlarge the discretion of the judge would diminish predictability so severely that settlements would be less likely"). 
It is the premise of such a view that discovery will have told the adversaries enough that the admissibility of crucial evidence may be thrown into the scales at the time of settlement negotiations. Or if the case goes to trial, the presumption is that discovery and settlement negotiations together will have told the adversaries enough that, if required, they can argue admissibility to the court based on comprehensive advance preparation.

This premise would seem to overlook special problems of litigation in federal criminal cases to which the new rules will apply; ${ }^{87}$ the exigencies of the rapidly expanding injunction litigation in the federal courts; and the continuing possibilities for surprise in trial of ordinary civil cases. ${ }^{88}$ These matters are discussed more fully below. ${ }^{89}$ For purposes of the present discussion it would seem at least reasonable to suppose that rules of evidence must work at the trial of cases and not only during settlement negotiations or in the preparation of pretrial office memoranda. If that is so, then the exigencies of the trial situation would seem to call for something other than what the proposed rules contemplate: remitting counsel and a court with minimum discretion to repeated consultation of a detailed rulebook.

Apart from the desire to limit judicial discretion in this context, the proposed rules also exhibit an intention to effectuate the important concerns of the litigants and of the system, in particular to preserve the jury from irrelevance, confusion and prejudice. The accumulated wisdom and scholarship of the past have been carefully saved and applied to each of the traditional headings of evidentiary rules. But it evidently did not appear to the draftsmen that radical simplification of the evidentiary rules might be accomplished without violence to those concerns and without disregard of the old learning.

To use again the example formerly given from the Federal Rules of Civil Procedure, the considerations that used to control whether or not a party might plead two claims together are now surely effectuated under rule 42 , allowing arrangements for separate trial; what is gained in the process is not only simplification of pleading, but perhaps a greater protection of the underlying policies. In contrast, the proposed Federal Rules of Evidence conform to established patterns. The rules govern-

${ }^{87}$ Proposed Fed. R. Evid. 101, 56 F.R.D. 194.

${ }^{88}$ Id. Cf. id. Rule 901 (a), Advisory Comm. Note, 56 F.R.D. 332-33 (observing that contingencies may arise in ordinary civil litigation).

${ }_{89}$ See Section IV infra; text accompanying notes 153,175 infra. 
ing the reception of hearsay evidence, for example, take the approach generally prevailing that hearsay is inadmissible but that there are a great many exceptions. ${ }^{90}$ The more than thirty enumerated exceptions in three categories ${ }^{91}$ exhaust the catalog of exceptions generally prevailing under state law, and there are academic niceties of distinction throughout. ${ }^{92}$ And yet it lay with the draftsmen to take the path of trusting properly instructed federal juries and the informed discretion of federal judges ${ }^{93}$ and by a stroke of the pen to make hearsay evidence, if probative, generally admissible. ${ }^{94}$ Evidence proffered under such a rule might be subject to the discretion of the court to keep it out for the reasons underlying the old enumerated exceptions-factors which the new rule, in the manner of Federal Rules of Civil Procedure 19 and 23, for example, might carefully set forth.

Other ways of making the rules of evidence simpler were equally available to the Advisory Committee. The kind of quibbling for which the proposed hearsay rules lay the basis might well have been obviated for trial to the court in nonjury cases, ${ }^{95}$ perhaps by the drafting of a set of minimal protective provisions.

${ }^{90}$ H.R. 5463, 93d Cong., 1st Sess., reprinted in 42 U.S.L.W. 10, would amend article VIII in some details.

91 Proposed Fed. R. Evid. 801, 56 F.R.D. 293 (by way of definition); id. Rule 803, 56 F.R.D. 300 (containing exceptions as to which the avallability of the declarant is immaterial); id. Rule 804, 56 F.R.D. 300 (containing exceptions applicable when the declarant is unavailable).

${ }^{42}$ See, e.g., id. Rule 801 (a)(2), 56 F.R.D. 300. Cf. Graham, supra note 55, at 288:

[T] he issue of whether non-assertive conduct is or is not hearsay is one that, while being beaten to death by the writers, would probably not be recognized in practice by more than $1 \%$ of the lawyers and judges in this state. Indeed, perhaps for this reason, there are only a handful of appellate cases that present the issue. Nonetheless, the drafters of the [California Evidence] Code take greai pride in having settled once and for all this burning question. (citations omitted).

${ }^{93}$ Graham, supra note 55, at 307: "The needs of reform have been clear for the last half-century: simplification of the rules, a presumption in favor of admissibility of evidence, and a large measure of discretion in the trial judge."

${ }_{94}$ See generally Ladd, The Relationship of the Principles of Exclusionary Rules of Evidence to the Problem of Proof, 18 MINn. L. REv. 506 (1934); Loevinger, Facts, Evidence and Legal Proof, 9 Western Res. L. Rev. 154 (1958); Weinstein, Probalive Force of Hearsay, 46 IowA L. REv. 331 (1961).

The Advisory Committee rejected this approach to hearsay "as involving too great a measure of Judicial discretion, minimizing the predictability of rulings, enhancing the difficulties of preparation for trial ...., and requiring substantially different rules for civil and criminal cases." Proposed Fed. R. Evid. art. VIII, Advisory Comm. Note, 56 F.R.D. 290: The functional consideration last noted is subject to the observation that the divergence required by the sixth amendment would merely parallel the existing divergence now required.by the fourth and fifth amendments, and preexisting statutory and rule material applicable only in federal prosecutions, e.g., Jencks Act, 18 U.S.C. $\$ 3500$ (1970). Moreover it may be desirable to develop more liberal hearsay rules in civil than in criminal cases, iparticularly in trials to the court alone. In England the Civil Evidence Act of 1968 renders hearsay generally admissible in civil cases subject to notice provisions. Civil Evidenć Act of $1968, c .64 \$ \$ 1-10$.

" 95 See Davis, Hearsay in Nonjury Cases, 83 Harv. L. Rev. 1362 (1970). 
Although important policies argue against allowing the trier of fact to hear what it is improper for him to consider, in view of the requirement of offers of proof ${ }^{96}$ it is transparent that the judge will at least know about such material in any event.

Other possibilities, on a lesser scale, present themselves. In lieu of the detailed limitations of proposed Article VI upon impeachment of witnesses, impeaching proof might have been made generally admissible subject to the court's discretion to cut it off on familiar relevancy analysis. ${ }^{97}$ Proposed Article IX on authentication of documentary and similar proof, and proposed Article $\mathrm{X}$ on the use of copies and originals, both present a formidable congeries of things for a trial lawyer to know and to line up with applicable hearsay provisions; yet it would seem possible to admit such evidence initially and then subject it (in the few instances where prior stipulation of authenticity has been unable to clear up a doubt) to the arts of the cross-examiner, to enable the trier to evaluate authenticity and related questions. This is not to state categorically hat any or all of these steps would in the end have been wist, but only to point out that at least they would have paralleled the kind of radical simplification of practice that the Federal Rules of Civil Procedure ushered in.

It is probable that the conservatism of the new evidentiary rules is traceable in part to the experience of the draftsmen of the Model Code of Evidence. ${ }^{98}$ It was widely believed ${ }^{99}$ that the Model Code of Evidence had failed to achieve enactment in any state because it was too radical. The Commissioners drafting the Uniform Rules of Evidence ${ }^{100}$ sought to succeed in furnishing a model for reform of state law by restating rather than revolutionizing existing evidentiary rules. ${ }^{101}$ Although the Uniform Rules also failed to achieve reform of state law, ${ }^{102}$ the suggestion that the new Federal Rules of Evidence be based in

${ }^{96}$ Proposed Fed. R. Evid. 103(2), 56 F.R.D. 194-95.

${ }^{97}$ Cf. Luck v. United States, 348 F.2d 763, 767-68 (D.C. Cir. 1965); CAL. Evid. Code $\S 788$ (West 1966). Luck has been overruled in the District of Columbia, however, see Dixon v. United States, 287 A.2d 89 (D.C. App. 1972), and has been rejected elsewhere, see, e.g., United States v. Garrison, 348 F. Supp. 1112, 1129 (E.D. La. 1972).

98 MOdel Code of Evidence (1942).

${ }^{99}$ See UNIForm Rules of Evidence, Prefatory Note 161 (1953).

${ }^{100} I d$. (1953).

101 See id. Prefatory Note 161.

${ }^{102}$ No state has adopted the Model Code. Only Kansas, the Canal Zone, and the Virgin Islands have substantially adopted the Uniform Rules. KAN. STAT. ANN. \$§ 60-401 to $60-470$ (1964); C. Z. CoDE, tit. 5, §§ 2731-2996 (1963); V.I. CodE ANN., tit. 5, §§ 77.1-956 (1967). Although the Uniform Rules of Evidence were the point of departure for recent enactments in California and New Jersey, those enactments are much modified to conform to particular state policies and traditions. "It is by now quite apparent that the Uniform Rules of Evidence have no chance of being enacted as uniform legislation in all the states." Spangenberg, supra note 1 , at 1066. The reasons for lawyers' general resistance to codification of the law of evidence are discussed in Section IV infra. 
part upon the Uniform Rules of Evidence ${ }^{103}$ has probably been carried out; ${ }^{104}$ in addition, state law materials and the newer codes have also been utilized, lending the proposed rules as much the aspect of a restatement as had the Uniform Rules.

Thus, the real precedent of the proposed federal evidence rules is not the Federal Rules of Civil Procedure, but the Uniform Rules of Evidence, and similar materials. The states have shown some interest in adopting the proposed federal evidence rules: the National Conference of Commissioners on Uniform State Laws is preparing an adaptation for state court use; ${ }^{105}$ the Supreme Court of Wisconsin is expected to adopt a modified version of the proposed rules; the Supreme Court of New Mexico has already done so; and Nevada adopted the 1971 preliminary draft with modifications. ${ }^{106}$ But if the history of state adoption of the Uniform Rules of Evidence and the Model Code of Evidence ${ }^{\mathbf{1 0 7}}$ is any guide, this early showing will not in fact develop into a significant trend. ${ }^{108}$

\section{F. Summary}

Thus, the arguments generally advanced as favoring new federal evidentiary rules are unpersuasive. No need for uniformity can be made out, other than for uniformity over the various federal jurisdictional headings, a job that can be accomplished without promulgation of a full-blown federal code of evidence. Nor has any such simplification of evidentiary law been accomplished by the proposed rules as would justify their promulgation to serve as a model for state reform, and thus indirectly as a route to conformity. The following sections will explore the

\footnotetext{
${ }^{103}$ See 1962 Preliminary Report, supra note 10, at 110; Estes, supra note 54, at 335; Joiner, supra note 67 , at 431 .

${ }^{104}$ See, e.g., Ladd, supra note 12, at 716 n.65; Proposed Fed. R. Evid. 103(a), 106, 201(b), 406(b), 407, 408, 411, 507, 607, 701, 704, 801, 008, Advisory Comm. Notes, 56 F.R.D. 195, 200, 204, 225, 225-26, 227-28, 230, 249, 266-67, 281, 284-85, 293-99, 347. ${ }^{105}$ Hearings, supra note 1, at 352 (testimony of Frank F. Jestrab, National Conference of Commissioners of Uniform State Laws).

${ }^{106} I d .546$ (reply statement of Professor Edward W. Cleary, Reporter to the Advisory Committee on Rules of Evidence, Judicial Conference of the United States).

${ }_{107}$ It might be argued that since the less radical Uniform Rules have been more successful in attracting the states than the Model Code, see note 102 supra, the proposed rules would stand a better chance of adoption by the states the more they adhered to established positions. $C f$. Blackmar, supra note 72, at 20: "The proposed rules are often more conservative than the Model Code or the Uniform Rules. Perhaps it is felt that a proposal of this nature has a better chance for adoption." If this means, however, that a very conservative federal model might immediately attract the same number of followers as have the Uniform Rules, then the argument is correct, but unimportant.

${ }^{108}$ It is possible that use of the proposed rules by federal courts will make them more attractive than the Uniform Rules could have been as a model. But it is unlikely that this consideration could outweigh the disadvantages of evidentiary codification. $C f$. Graham, supra note 55. Even the Federal Rules of Civil Procedure, under no such disadvantages, have failed to be adopted by almost half the states, 35 years after their promulgation.
} 
proposition that absent such conformity, a detailed code of sophisticated, scholarly new federal evidentiary rules may well contribute to the difficulties of trial lawyers in both sets of courts.

\section{Disadvantages of Uniform Federal Evidence Rules: Evidence Distinguished from Procedure Generally}

\section{A. Unanticipated Evidence and the Necessity of Instantaneous Grasp of Evidence Rules at Trial}

Economy of federal lawmaking effort to one side, it would appear that the argument for conformity of federal court procedures to forum state rules has historically been based for the most part upon the consideration of convenience to the trial bar. Prior to 1938 it had always been understood that trials in all courts could most conveniently be handled by reference to a single set of procedural rules which was uniform within a particular state. ${ }^{109}$

Evidentiary rules present a more imperative case for intrastate conformity than do other rules of pleading and practice. The feature that distinguishes many rules of evidence from rules of civil procedure generally is that the former tend to call for split-second discriminations in application. ${ }^{110}$ An objection to evidence or an argument in support of proffered but arguably objectionable evidence must be made quickly or waived. ${ }^{111} A$ ruling upon objected-to evidence must be made at once by a judge under pressure to avoid error. Although a lawyer can familiarize himself at his leisure with procedural rules governing such things as the filing of pleadings, and even with evidentiary rules governing anticipated proof, the lawyer who is confronted with unforeseen testimony, or whose witness is confronted with unforeseen examination, or who finds that he has unforeseen evidence to offer, must know at once whether these are objectionable or supportable.

It is necessary at this point to meet the implicit argument of the draftsmen of the proposed rules that evidentiary issues do not come as a surprise to trial lawyers: counsel have had discovery, so they know what the evidence will be; they have attempted

${ }^{109}$ See notes 43-44 supra \& accompanying text.

110 See Restatement, supra note 28, $\$ 138$, comment $a$ (1971), reproduced at text accompanying note 139 infra; Estes, supra note 54, at 331-32; McCormick, The New Code of Evidence of the American Law Institute, 20 TEx. L. REv. 661,662 (1942); cf. Chicago \& N.W. Ry. v. Kendall, 167 F. 62, 70 (8th Cir. 1909).

in Subject to the plain error rule, codified in proposed rule 101(d). 
settlement and in the course of negotiations have learned the nature of each other's objections to the evidence; they have had time to research and prepare evidentiary arguments for the benefit of the court. In this view, the real value of evidentiary rules is to help settle cases by making evidentiary issues predictable in outcome, and elaborately detailed rules can best accomplish that result. ${ }^{112}$

But it would seem that the possibilities of surprise in trial of cases have not been fully appreciated by the draftsmen. First, their view appears to have minimized the special circumstances obtaining in the federal criminal jurisdiction, to which the proposed rules will apply. ${ }^{113}$ Criminal cases do not profit from the civil discovery devices; indeed, the Constitution protects criminal defendants from much discovery; ${ }^{114}$ rule 16 of the Federal Rules of Criminal Procedure is limited in scope and can be conditioned on discovery by the defense; and the prosecution is required to divulge certain matters only at trial. ${ }^{115}$ Additionally, the decision whether to settle a criminal case (that is, whether to negotiate a plea of guilty) fairly depends upon other factors; and, where evidentiary factors enter, they are likely to be of constitutional dimension, and thus beyond the scope of the proposed rules of evidence. ${ }^{116}$ Moreover - to take a realistic view-many criminal defenses are prepared by a specialized bar, members of which are often under the pressure of caseloads which must sharply confine their pretrial investigations.

Second, the draftsmen also appear to have overlooked the important jurisdiction exercised by federal courts today over actions for injunctive relief, a jurisdiction increasingly busy as new classes of plaintiffs explore new remedial possibilities. With far greater frequency than in the past, evidentiary hearings are convened on short notice to consider applications for temporary and preliminary relief against hospitals, prisons, school boards, corporations and other institutions. Little or no formal discovery will have been previously available to litigants in such cases, nor will all important evidence be available in advance; it is the very nature of these applications for injunctive relief that they are prosecuted with dispatch under the alleged threat of imminent,

${ }^{112}$ See text accompanying note 86 supra.

113 Proposed Fed. R. Evid. 1101, 56 F.R.D. 347. The following textual observations are also applicable in varying degrees to state courts. Note that FED. R. CRrM. P. 16 ameliorates the orthodox position to some extent, by providing for limited discovery in federal criminal cases.

${ }_{114}$ See, e.g., Feldman v. United States, 322 U.S. 487 (1944) (fifth amendment).

${ }^{115}$ Cf. Jencks Act, 18 U.S.C. \$ 3500 (1970).

${ }^{116} C f$. Proposed Fed. R. Evid. 403 \& Advisory Comm. Note, 56 F.R.D. 218-19. 
irreparable harm. Furthermore, under the Federal Rules of Civil Procedure such proceedings may terminate the litigation by consolidation with trial on the merits. ${ }^{117}$

Finally, the draftsmen seem to have unduly discounted the continuing possibilities for surprise in trial of ordinary civil cases. ${ }^{118}$ A question or line of examination at trial may be unanticipated; witness subpoenas duces tecum may turn up documentary proof uninvestigated by either party; 119 hearsay testimony may be injected despite the conscientiously worded questions of counsel. ${ }^{120}$ Considering these kinds of problems, it may be fairly agreed that in any evidentiary hearing lawyers do feel the necessity to react quickly to unanticipated objectionable evidence and to their adversaries' unanticipated objections.

\section{B. Confusion Developed by Parallel Systems of Evidence Rules in Federal and State Courts}

This necessity for speed has tended to render lawyers' habitual reactions to evidence unresponsive to change. ${ }^{121}$ It is anticipated that a new set of evidentiary rules may not be completely utilizable for this reason, at least by this generation of trial lawyers. ${ }^{122}$ The necessity for speed in reaction may account for the noted tendency ${ }^{123}$ of some trial lawyers to make ineffective use of even the established rules of evidence. Courtroom observation demonstrates that lawyers object to evidence on

11 FED. R.' CIV. P. 65(a)(2). Nor have the proposed rules distinguished injunction cases by allowing for more flexible evidentiary standards in cases tried to the court. $C f$. Davis, supra note 95.

${ }_{118}$ But cf. Proposed Fed. R. Evid. 901(a), Advisory Comm. Note, 56 F.R.D. 333 (observing that "contingencies" may arise in ordinary civil litigation requiring proof of authentication or identification); id. Rule 1001, Advisory Comm. Note, 56 F.R.D. 217 ("unanticipated document").

${ }_{119}$ Based on the author's observation, it is common for lawyers to neglect discovery and even informal pretrial investigation along certain lines for tactical reasons; the hope is to turn up favorable surprises at trial. Thus, in a recent trial involving mental damage to a minor, the school nurse and principal were questioned for the first time by the defense on the stand, and testified that the plaintiff was lying if she said she had had fainting fits at school. Malone v. Sears, Roebuck \& Co., Civil No. 67-844G (D. Mass., Mar. 31, 1970). The "unanticipated document" is recognized in Proposed Fed. R. Evid. 1001, Advisory Comm. Note, 56 F.R.D. 217.

${ }^{120}$ See text accompanying note 175 infra.

121 The familiar example is the taking of exceptions in federal court despite FED. $R$. Civ. P. 46, abolishing exceptions. See Weinstein, supra note 10 , at 360 .

${ }^{122}$ See Weinstein, supra note 10, at 360: "Within the courtroom the lawyer's ... almost involuntary reflexive action . . . will not be radically and immediately affected, whatever the new rule."

${ }^{123}$ See Cleary, Evidence as a Problem in Communicating, 5 VAND. L. REv. 277 (1952); Graham, supra note 55, at 280-86; 1962 Preliminary Report, supra note 10, at 109, citing Estes, supra note 54, at 11; Report of the Committee on Improvements in the Law of Evidence, 63 A.B.A. REP. 570, 576 (1938). 
nonexistent grounds; for example, the evidence is said to be "incompetent" or "self-serving." 24 That even the most up-todate code may present subtleties of scholarly analysis ${ }^{125}$ which lawyers cannot remember or employ under pressure may explain why lawyers tend to make little use of codifications of the law of evidence. ${ }^{126}$ Judges, for similar reasons, have sometimes administered evidentiary law with suprising flexibility. ${ }^{127}$

For such reasons the argument for reform of the law of evidence is for the most part directed at the elaboration, bulk and complexity of existing rules, ${ }^{128}$ and no substantial authority has hitherto taken the position that predictability is such an overriding desideratum that reform should lie in the direction of greater elaboration, bulk or complexity. "What is lamented is [the] infinitesimal, meticulous, petty elaboration into a mass not capable of being perfectly mastered and used by everyday judges and the practitioners." ${ }^{29}$ The draftsmen of the proposed rules also gave it as one of their original goals to simplify the law of evidence. ${ }^{130}$

That they have failed in that goal may fairly be argued. ${ }^{131}$ But there is the further consideration that, whether or not one regards the proposed rules as simple, the rules will have to be learned by trial lawyers in addition to the rules they will continue to employ in state court trials. ${ }^{132}$ In furnishing additions and exceptions for one context only, the proposed rules inescapably contribute to the complexity, as well as the sheer bulk, of the

${ }^{124}$ See Graham, supra note 55, at 281.

125 See id. 287: A lawyer examining some parts of the California Evidence Code "is hard put to know whether he is examining the work product of lawyers or theologians." ${ }_{126}$ See Hearings, supra note 1, at 209, 211, 248, 300; Graham, supra note 55, at 279 (California Evidence Code). Cf. note 102 supra \& accompanying text (discussing failure of the Uniform Code of Evidence to achieve wide state enactment).

${ }^{127}$ See J. Thayer, A Preliminary Treatise on Evidence at the Common laty 527-29. Judge Augustus Hand claimed to have admitted all probative evidence routinely without reversal on appeal. See 19 ALI Procendings 225 (1942); Clark, Forward to the Symposium on the Uniform Rules of Evidence, 10 RUTGERS L. REv. 479, 480 (1956). See also Estes, supra note 54, at 334 (making the same claim); Graham, supra note 55, at 299. Cf., e.g., People v. Spriggs, 60 Cal. 2d 868, 389 P.2d 377, 36 Cal. Rptr. 841 (1964) (ruling that California hearsay rule does not exclude evidence necessary to the "penal interest" of finding "truth").

${ }_{128}$ See 1962 Preliminary Report, supra note 10, at 109; Report of the Committee on Improvements in the Law of Evidence, supra note 123, at 576-77.

${ }_{129}$ Report of the Committee on Improvements in the Law of Evidence, supra note 123, at 576. See also Estes, supra note 54 , at 332 . at 716 .

${ }^{130}$ See 1962 Preliminary Report, supra note 10, at 108-10. See also Ladd, supra note 12,

${ }_{131}$ See, e.g., Broun, supra note 69; Davis, supra note 71. Cf. text accompanying notes 66-72 supra.

${ }_{132}$ To the extent that this has always been the case in federal trials under FED. R. Crv. P. 43(a) and FED. R. CRIM. P. 26, codification of detailed rules will operate only to make the situation more acute and less subject to change. See text accompanying notes 141-79 infra, 126 supra. 
corpus of evidentiary rules. ${ }^{133}$ That the draftsmen of the proposed rules have directed the application of state rules in some instances, ${ }^{134}$ or that certain of the proposed rules are bound to coincide with state rules in some cases, ${ }^{135}$ does not ease the fundamental difficulty of a trial lawyer's position in either set of courts. When he is rising to his feet to object there is no time for cogitation along the lines of: "Or is it the other way around?"

The functional considerations explored here are reflected in the underlying rationale of the basic conflicts-of-law rule that questions of evidence ${ }^{136}$ are generally for the forum state. ${ }^{137}$ This rule is an expression of the fundamental desideratum of all choices of law, that the law applied be characterized by "ease in determination and application." ${ }^{38}$ As the commentary to the Second Restatement's evidence rule explains:

Considerations of efficiency and convenience require that questions ... of evidence ... should usually be determined by the local law of the forum. The trial judge must make most evidentiary decisions with dispatch if the trial is to proceed with reasonable celerity. The judge should therefore, as a general rule, apply the local law of his own state. ${ }^{139}$

The following section will attempt to demonstrate, using examples from the proposed rules, how they would tend to make more difficult the determination and application of evidentiary law in both sets of courts.

${ }^{133}$ The proposed rules may also require analyses differing from those customarily employed in arguing counterpart state rules, and may be characterized by differing correlational patterns. See text accompanying note 176 infra.

${ }^{134}$ E.g., Proposed Fed. R. Evid. 302, 903, 56 F.R.D. 211, 340. H.R. 5463, supra note 7, would amend Rule 501 to the same end. See also Proposed Fed. R. Evid. 902(9), 56 F.R.D. 337. Despite the unfortunate terminology in the rule, presumably the Uniform Commercial Code would control. See id. Advisory Comm. Note, 56 F.R.D. 339.

${ }^{135}$ Compare, e.g., Proposed Fed. R. Evid. 705, 56 F.R.D. 285, with N.Y. Crv. PRAC. $\S 4515$ (McKinney 1963).

${ }_{136}$ See also RESTATEMENT, supra note $28, \S 122$ with respect to procedure generally.

${ }^{137}$ Restatement, supra note $28, \S 138$.

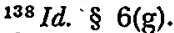

${ }^{139} \mathrm{Id}$. $\S 138$. This kind of result will be appropriate not only for procedural conflicts but even where the question is one of substantive law, whenever application of theoretically governing rules simply cannot be expected to work. For example, although the Second Restatement takes the position that performance of a contract and validity of a contract are governed by the same law, in the absence of effective stipulation by the parties, id. $\$ 188$, details in performance of the contract (such as whether Monday performance may be substituted for Sunday performance) are governed by the law of the place of performance, id. $\$ 206$, illustration 2 . A contrary rule simply will not work, for example, in a state where Sunday performance is prohibited. So in the case of evidence rules where functional analysis tends fairly to the conclusion that nonconformity to local details of evidentiary law will not work, a contrary choice of uniform federal rules for federal courts would seem by analogy to be not only unnecessary, but also incorrect. This analogy was suggested by Professor Donald T. Trautman. 


\section{Analysis of Examples from the Proposed Federal Rules of EvidenCE ${ }^{140}$}

Paradoxically (to those accustomed to the Erie viewpoint), the problems outlined above may become more acute as evidentiary rules become less "substantive" 141 in content and more arbitrary. Such rules, often statutory, typically prescribe precise limitations upon the admissibility of a class of evidence.

\section{A. Impeachment of Witnesses by Prior Criminal Convictions}

A good example is furnished by the Massachusetts statute providing for impeachment of a witness' credibility by proof of a criminal conviction. ${ }^{142}$ Under this statute, the credibility of an opponent's witness may be impeached by the record of a felony conviction within ten years of its entry, or of a misdemeanor conviction within five years of its entry. These time limitations do not apply where another criminal conviction has occurred within the ten or five years, respectively. In the case of a felony, where a minimum term of imprisonment has been imposed, the ten-year period runs from the date of expiration of the minimum term, rather than from the date of judgment of conviction. No distinction is taken between crimen falsi and other crimes, although some commentators believe that for purposes of impeaching credibility the distinction ought to be made; ${ }^{143}$ but it will be agreed that the scheme here outlined is not unrefined. Where impeachment of this kind comes as a surprise to the lawyer summoning the witness-and, as we shall see, it frequently does-he must test it at once against his memory of these details.

Under the proposed Federal Rules of Evidence, ${ }^{144}$ a Massachusetts trial lawyer in the Federal District Court for the

${ }^{140}$ The version of the proposed rules which is analyzed in this Section is that promulgated by the Supreme Court, Proposed Fed. R. Evid., 56 F.R.D. 183. H.R. 5463 is not employed here as the model for analysis since its vitality, at the time of this writing, is not clear; the Senate will almost certainly introduce further changes to the original proposed rules.

${ }^{141}$ See also text accompanying note 193, infra.

142 Mass. Gen. LAwS ANN. ch. 233, § 21 (1956). The author, a member of the Massachusetts Bar, has used illustrative materials from that state, but these remarks will apply more generally as well. $C f$. Leach, supra note 47 , at 583 n.117.

The rules governing impeachment of a criminal defendant by such means are not here considered, nor is the broad question of the limitations upon extrinsic impeachment evidence generally.

${ }^{143}$ See Model Code of Evidence Rule 106, commentary (1942); Uniform Rules of Evidence Rule 21, commentary.

${ }_{144}$ Proposed Fed. R. Evid. 607, 609, 56 F.R.D. 266, 269-70. The current proposal in Congress would amend proposed rule 609 in some details not important to this analysis. H.R. 5463, 93d Cong., 1st Sess., reprinted in 42 U.S.L.W. 8. 
District of Massachusetts will have to familiarize himself with the following variations upon the foregoing state scheme:

(1) Proof of a conviction for impeachment purposes may be made by evidence of that conviction and not solely by the record of it; $^{145}$ the federal best evidence ${ }^{146}$ rule probably does not apply.

(2) There are two provable categories of criminal conviction, but they are slightly different from those obtaining under state law: felonies, and misdemeanors involving "dishonesty or false statement."147

(3) There is no rule against impeaching one's own witness by proof of prior conviction. ${ }^{148}$

(4) The federal rule introduces an exception for juvenile adjudications and another for crimes pardoned or annulled. Such pardon or annulment must have been based upon a showing of either rehabilitation or of innocence; and if the showing was of rehabilitation, the witness must not have been convicted of a subsequent crime. ${ }^{149}$

(5) The period of admissibility of a provable conviction is ten years, with no five-year feature for misdemeanors. ${ }^{150}$

(6) Finally, the ten years begins to run, not from the date of conviction, but from the time of release from confinement with respect to any most recent conviction or from the date of the expiration of a sentence or probationary period for the conviction sought to be proved, whichever is the later. ${ }^{151}$

Based on the foregoing, a Massachusetts trial lawyer in either state or federal court may find himself thinking: "Or is it the other way round?" more often than even the draftsmen of the proposed rules might have thought desirable. The chances are high that counsel will have to object to or argue in favor of evidence of this type before he has time to recall and sort out his theories. This difficulty is not an insignificant one. Such impeachment is frequently unexpected, the result of the factors outlined previously 152 as contributing to the continuing possibilities for surprise in criminal, equity and even ordinary civil

${ }^{145}$ See Commonwealth v. Shep̄pard, 313 Mass. 590, 595-96, 48 N.E.2d 630 635-36, cert. denied, 320 U.S. 213 (1943); Proposed Fed. R. Evid. 803(22), 56 F.R.D. 303.

${ }^{146}$ Proposed Fed. R. Evid. 1002, 1003, 1005, 56 F.R.D. 342-43, 345.

${ }^{147}$ Id. Rule 609(a), 56 F.R.D. 269.

${ }^{148}$ Id. Rule 607, 56 F.R.D. 266.

${ }^{149}$ Id. Rule 609(c)-(d), 56 F.R.D. 270.

${ }^{150}$ Id. Rule 609(b), 56 F.R.D. 269-70.

${ }^{151}$ Id.

${ }^{152}$ See text accompanying notes $109-22$ supra. 
cases. It is, in part, also the result of factors peculiar to the problem of prior convictions.

Criminal cases, in particular, in both state and federal courts, will continually produce the surprise prior conviction of a supporting witness. It is the extraordinary criminal case in which an affirmative substantive defense is mounted; investigation of a defendant's own character witnesses and other supporting witnesses must generally be quite limited. Yet the prosecution often has the resources, if the witness seems worth impeaching, to search out and obtain the impeaching information overnight, or even during a recess. ${ }^{153}$

Another example, which may vary in significance with the geographical location of the court in which the case is being tried, is furnished by maritime cases. An enormous federal jurisdiction over ordinary seamen's injuries in admiralty is shared by the state courts under the so-called "Saving Clause." 154 These cases continually produce the surprise prior conviction of an uninvestigated supporting witness; the sea apparently provides a job source for convicted men, and it is impracticable in these fairly routine tort cases to investigate the criminal involvements of one's own supporting witnesses, whose jobs involve travel to other jurisdictions, sometimes other countries.

For the price paid in convenience and efficiency, is the proposed federal rule substantially better than a rule which would require conformity to whatever the state rule happened to be? It would be difficult to argue that the proposed federal rule accords with the expressed goal of its draftsmen to simplify the law of evidence, ${ }^{155}$ though that goal does seem to have been within reach. ${ }^{156}$ Instead, the draftsmen have supplied a rule

${ }^{153}$ Based on the author's experience, the frequency of surprise impeachment is recognized in the common tactic of keeping certain witnesses away from the courtroom until they are to testify. Even in well-financed civil litigation, production of a witness-list, although frequently sought, is often strenuously opposed. Some lawyers defer even intramural consideration of the possibility of using someone as a witness in order to avoid disclosing him to the opponent under questioning by the court at pretrial. Relying on the corridor interview, or gambling that the contents of the witness' subpoenaed documents will be favorable, trial counsel does nothing to contact or interview the witness; then, a day before he should testify, trial counsel will have a sudden inspiration and a subpoena will be served.

15428 U.S.C. § 1333(1) (1970).

${ }^{155}$ It is more detailed, for instance, than the illustrative Massachusetts statute, and much more complex than earlier models furnished by MODEL CODE OF EVIDENCE rule 106 (1942); UNIFORM RULE of EvidENCE 21. These latter simply provided for impeachment of credibility by proof of convictions for crimen falsi, remitting such difficulties as remoteness in time (essentially a problem of relevancy) to the discretion of the court.

${ }_{156}$ The draftsmen could, for example, have left reception of this sort of evidence to the discretion of the court. Cf. Luck v. United States, 348 F.2d 763, 767-68 (D.C. Cir. 1965); CALIF. Evid. CodE $\$ 788$ (West 1966). However, because Congress had seemingly rejected the doctrine of Luck for the District of Columbia in the Court Reform Act of 
complex in its own detail and additionally complex in its employment when it competes for an attorney's recollection with a similarly detailed state rule. As to reform, although the proposed federal rule employs the notion that the crime used for impeachment should have to do with falsehood, it obscures the point by using the Uniform Rule language about "dishonesty,"157 and it blunts the edge of reform in any event by limiting the distinction to misdemeanors, a step backward from the position taken by both the Model Code and the Uniform Rules. ${ }^{158}$ As for the variations in time periods and in dates of their onset, these are, of course, arbitrary. ${ }^{159}$ Weighing these considerations, it is difficult to see why the particular rule proposed would be superior to one requiring conformity to the forum state rule on this issue.

\section{B. Hearsay}

The impeachment example concerns a set of arbitrary limitations upon admissibility of one very narrow class of evidence. The same sorts of difficulties are associated with federal rules of more pervasive application and presumably less arbitrary content as well, if they are drafted in a detailed way and tend to differ along unpredictable lines from parallel state provisions. In addition, there may occur further difficulties for the bar in mastering the interworkings of complex rules as they mesh with each other in ways that also may deviate unpredictably from existing state law. This is precisely the situation raised by the proposed federal hearsay rules. ${ }^{160}$

With hearsay, as with impeachment, one cannot help striking a regretful note for lost opportunities. The admissibility of hearsay has been understood for generations to depend, at bottom, upon a few broad qualitative factors: the need for the proof (its probative value); the difficulty of getting it from

1970, D.C. Code ANN. § 14-305 (1973), see Dixon v. United States, 287 A.2d 89, 91 (D.C. App. 1972), the draftsmen felt bound to avoid this alternative. See Hearings, supra note 1, at 68 (testimony of Judge Albert B. Maris).

The alternative of excluding this sort of impeaching evidence entirely has also been widely recommended. See Blakney v. United States, 397 F.2d 648 (D.C. Cir. 1968) (McGowan, J., concurring); Ashcraft, Evidence of Former Convictions, 41 CHI. B. REc. 303, 307 (1960); Ladd, Credibility Tests-Current Trends, 89 U. PA. L. REv. 166, 176-78 (1940); Spector, Impeaching the Defendant by His Prior Convictions and the Proposed Federal Rules of Evidence, 1 LoyolA U. CHI. L.J. 247 (1970).

${ }^{157}$ See UNIFORM Rule OF Evidence 21.

${ }^{158}$ Compare Proposed Fed. R. Evid. 609(c), 56 F.R.D. 269, with MODEL CODE OF Evidence Rule 106 (1942); Uniform Rule of Evidence 21.

159 See Spector, supra note 156 , at 256.

160 See Proposed Fed. R. Evid. art. VIII, 56 F.R.D. 293-331. H.R. 5463 would change the hearsay rules in ways not important to this analysis. 
another source; the intrinsic reliability of the hearsay source under the circumstances. ${ }^{161}$ This is the stuff of which a comprehensive rule of court might be fashioned. A simplified federal hearsay rule might have directed court and counsel toward the fundamental policy concerns we have noted (need, reliability, unavailability). ${ }^{162}$

Instead, the draftsmen opted ${ }^{163}$ to string out the hearsay rule among three categories of detailed exclusions and exceptions. Some hearsay is excluded from the operation of the rule by way of definition, including nonassertive conduct ${ }^{164}$ and prior statements by witnesses, ${ }^{165}$ and by such familiar exclusions as statements offered other than for their truth, ${ }^{166}$ and admissions by a party opponent ${ }^{167}$ (although this last is more typically conceived as an exception rather than an exclusion). There follow two broad categories of exceptions, under one of which the hearsay declarant must be unavailable ${ }^{168}$ and under the other of which his availability is immaterial. ${ }^{169}$ The theoretical basis of the distinction between the two classes of exceptions is said to be their degree of reliability, ${ }^{170}$ but it may not be clear to some practitioners why former testimony, statements under belief of impending death and statements against interest, ${ }^{171}$ for example, are less reliable than present sense impressions, excited utterances and recorded recollections. ${ }^{172}$ The problem of mastering the distinction between rules 803 and 804 aside, the individual exceptions thereunder contain further limitations and qualifications, some of which appear quite optimistic about the capacity of trial lawyers. Rule 803, for example, allows as an exception:

[a] statement of the declarant's then existing state of mind, emotion, sensation, or physical condition (such as intent, plan, motive, design, mental feeling, pain, and

161 See generally C. MCCoRMick, Handbook of the LAW of Evidence 626 (1954): "It now seems strange that the courts should have attempted to answer this by defining in sharp categories the special situations when secondary proof would be required"; J. Wigmore, Student Mandbook of the Law of Evidence 247 (1935).

${ }_{162}$ See notes $90-95$ supra \& accompanying text.

${ }_{163}$ See authorities cited note 94 supra. supra.

${ }^{164}$ See Proposed Fed. R. Evid. 801(a)(2), 56 F.R.D. 293. For a critique, see note 92

165 Proposed Fed. R. Evid. 801(d)(I), 56 F.R.D. 293.

${ }^{166}$ Id. Rule 801 (c), 56 F.R.D. 293.

${ }^{167}$ Id. Rule 801(d)(2), 56 F.R.D. 293.

${ }^{168}$ Id. Rule 804, 56 F.R.D. 320.

${ }^{169}$ Id. Rule 803, 56 F.R.D. 300.

${ }^{170}$ See id. Rule 803, Advisory Comm. Note, 56 F.R.D. 303.

${ }^{171}$ See id. Rules 804(b)(1), (3)-(4), 56 F.R.D. 321.

172 See id. Rules 803(1), (2), (5), 56 F.R.D. 300. 
bodily health), but not including a statement of memory or belief to prove the fact remembered or believed unless it relates to the execution, revocation, identification, or terms of declarant's will. ${ }^{173}$

The scheme here outlined, is, like the rest of the proposed rules, not particularly simple. The parallel provisions of state law are likely to be almost as complex. ${ }^{174}$ The problem of having to choose among vaguely recollected provisions of these parallel systems under stress of trial is inevitable. Concededly the major hearsay questions in most litigation may be researched in advance: the admissibility of the surveyor's report, the doctor's notes, the out-of-court identification. But it is probably impossible to avoid continual reception of what is technically hearsay in any evidentiary hearing; and in any event, as we have seen, injunction proceedings and criminal cases will produce major items of unanticipated hearsay.

In whatever court a trial lawyer finds himself, then, he will be confronted by the same problems noted in our earlier discussion about impeachment: deciding what general exception applies to the case and which of two varying versions to argue. ${ }^{175} \mathrm{~A}$ further difficulty lies in coordinating any one group of rules with the other rules and then keeping clear the distinctions between the interaction among the rules under state law and the interaction under federal law. For example, a document may be selfauthenticating but nevertheless inadmissible as hearsay in one set of courts; yet in the other set of courts it may turn out not to be hearsay but inadmissible if an authenticating foundation has not been laid; and to both sets of requirements must be added the conflicting systems' positions with respect to best evidence and the related requirement of "originals." 176 Given the pervasiveness of the hearsay issue, the complexity of state hearsay rules, and the failure of the proposed federal rules to effect substantial reform, we may reasonably conclude that introduction of the new federal rules will create problems in determination and

${ }^{173}$ Id. Rule 803(3), 56 F.R.D. 300 (emphasis added). See also, e.g., id. Rules 803(5), (7), 804(b)(2), (4), 56 F.R.D. 300-01, 321.

${ }_{174}$ The accretions of state hearsay rules have themselves for generations been under fire as being haphazard, accidental, unrefined, and illogical. See generally authorities cited note 95 supra.

${ }^{175}$ For a survey of significant variations between the proposed federal hearsay rules and the weight of state authority, see Falknor, Hearsay, 1969 LAw \& Soc. Order 591. Note also the learned summary of Mr. George Spiegelberg, American College of Trial Lawyers, Hearings, supra note 1 , Supp. 68.

${ }_{176}$ See generally Proposed Fed. R. Evid. 803(6)-(17), 804(a)-(b)(1), 901(b)(7), 902, 1001-07, 56 F.R.D. 300-02, 320-21, 331-32, 336-37, 340-46. 
application of evidentiary law which would clearly outweigh any federal interest in the specific provisions of the proposed hearsay rules, or the federal interest in having specific hearsay rules made distinctly federal.

This Section has briefly focused upon a particular rule governing impeachment, and, in cruder outline, upon a broad, complex set of rules governing exceptions to the hearsay rule. But it would seem that similar analysis would produce similar conclusions in many of the remaining areas of evidentiary law. Rules controlling character evidence and evidence of characteristic or related behaviors, ${ }^{\mathbf{1 7 7}}$ identification and authentication of nondocumentary evidence, ${ }^{178}$ and even such matters as the taking of judicial notice ${ }^{\mathbf{1 7 9}}$ may become the subject of unanticipated controversy. The Advisory Committee Notes reveal the variety of state law on these questions and the selective quality of the proposed federal rules.

\section{Toward a Comprehensive Choice-of-Law Rule FOR THE RECEPTION OF EVIDENCE in All Federal Courts}

The foregoing sections have argued that the adoption of a code of comprehensive new federal evidentiary rules must result in grave inconveniences in trials in both state and federal courts, and that this consideration weighs heavily against their adoption. But the functional problems considered above do not indicate that all current evidentiary problems in the federal courts would be better handled by doing nothing. Indeed, the proposed rules would at least accomplish the unification of evidentiary rules under all headings of federal jurisdiction.

The genuine need for unification of evidentiary rules has already been pointed out. ${ }^{180}$ But the problem ought to be amenable to solution by means less disruptive than the promulgation of a comprehensive federal evidence code. A statutory federal choice-of-law provision mandating reference to state evidentiary law in all federal cases would probably be the simplest way of achieving that unification while improving, rather than causing further deterioration in, the desired conformity of

${ }^{177}$ E.g., id. Rules 404-06, 608, 56 F.R.D. 219-23, 267.

${ }^{178}$ E.g., id. Rules 901, 902, 56 F.R.D. 331-32, 336-37.

${ }^{179}$ Id. Rule 201, 56 F.R.D. 201. See generally Davis, supra note 71 (extremely critical of the inconvenience of proposed rule 201 ).

${ }^{180}$ See text accompanying notes 58-61 supra. 
evidence rules in federal courts to those of the courts of the state in which they sit.

Rule 43(a) of the Federal Rules of Civil Procedure furnishes some precedent for the use of a federal choice-of-law rule for evidence. The rule admits all evidence

which is admissible under the statutes of the United States, or under the rules of evidence heretofore applied in the courts of the United States on the hearing of suits in equity, or under the rules of evidence applied in the courts of general jurisdiction of the state in which the United States Court is held.

Stated simply, the rule provides that both federal and state evidentiary law will apply in all civil cases, the choice to be made according to whichever rule favors the reception of the evidence. Although the provision came early under serious scholarly criticism, ${ }^{181}$ it has become increasingly clear that rule $43(\mathrm{a})$ is "working better than these commentators had expected."182

However, rule 43(a) does not apply in criminal cases, ${ }^{183}$ and although it theoretically applies in bankruptcy and in admiralty, ${ }^{184}$ it has never been clear how far outside the diversity jurisdiction the rule retains vitality. It has been shown that in cases where the United States is a party, little use is made of state evidentiary decisions, and that reference to state law of evidence is uncommon in federal question cases and infrequent in admiralty and bankruptcy. ${ }^{185}$ Thus, unification of the evidentiary rules in federal courts has not been accomplished. ${ }^{186}$ Furthermore, rule 43 (a) has fostered considerable confusion about the extent to which the federal courts are free to fashion their own common law of evidence under the clause referring to "the rules of evidence heretofore applied in . . . suits in equity." 187 Finally, rule 43 (a) does little to discourage the further elaboration of two separate bodies of evidentiary law in each state. ${ }^{188}$ None of these

${ }^{18 I} 1 \mathrm{~J}$. WIGMORE, EVIDENCE 200-04 (3d ed. 1940); Green, The Admissibility of Evidence Under the Federal Rules, 55 HARv. L. REv. 197 (1941).

1821962 Preliminary Report, supra note 10, at 89-90; J. MOORE, FEDERAL Practice If 43.01 [7] (2d ed. 1971). It should be noted that under the proposed rules the pattern favoring admissibility will be lost.

${ }^{183}$ Federal common law of evidence applies in criminal cases, according to FED. R. Crim. P. 26.

${ }_{184}$ See note 61 supra.

${ }_{185}$ See Weinstein, supra note 10, at 377-78 (Sherman Appendix).

${ }^{186}$ See 1962 Preliminary Report, supra note 10, at 98, 115.

${ }^{187}$ See, e.g., id. 98, 115; Degnan, supra note 12, at 276; Green, Federal Civil Procedure Rule 43(a), 5 VAND. L. REV. 560 (1952); Comment, Federal Rule 43(a): The Scope of Admissibility of Evidence and the Implications of the Erie Doctrine, 62 CoLuM. L. Rev. 1049 (1962); Comment, Rule 43(a) and Erie-The Conflict in the Sixth Circuit, 34 TENN. G. Rev. 671 (1967). text.

${ }_{188}$ As to the significance of this problem, see notes 132-36 supra \& accompanying 
problems would arise if instead of rule 43(a) we had a clear choice-of-law provision generally opting for state law, even in criminal, admiralty, bankruptcy and federal question cases.

Objection might be made that state law cannot deal with certain evidentiary problems which may be unique to substantively federal cases. Of course this objection can be of significance only, if at all, in those relatively few areas in which federal courts retain exclusive jurisdiction. On the whole, the power of common law judges to find analogies would seem to undercut this objection to the extent that the problem is real.

Particular objection might be made to the use of state evidentiary rules in federal criminal prosecutions, where federal substantive policies are of overriding concern. It should be pointed out that much of the force of this objection may be removed by appropriate exceptions, discussed in the following paragraph. But it would seem that the objection lacks force initially in view of the fact that deference to state law to supply even substantive content to federal criminal law ${ }^{189}$ has been an appropriate and workable result where other strong national policies require it. ${ }^{190}$

Objection may also be made that such a choice-of-law rule would inevitably be subject to too many exceptions to work. Yet, upon reflection, the kinds of exceptions likely to arise are also exceptions to the proposed Federal Rules of Evidence. The most important example is the exception for evidentiary questions of constitutional dignity. ${ }^{191}$ This exception would be at least as workable under the suggested choice-of-law rule as under the proposed rules, because state law is also, for the most part, subject to federal constitutional requirements. The suggestion has been made ${ }^{192}$ that at the very least state privileges should not be applied in federal prosecutions. The point is well taken, because the national policies at stake will outweigh the local interests embodied in the privileges, while functional problems of the sort discussed above would be less likely to arise. ${ }^{193}$ Other exceptions, of broader application than the two exceptions noted, may be necessary wherever federal evidentiary rules of great vitality embody matters of overriding national policy, such

${ }^{189}$ See, e.g., Assimilative Crimes Act, 18 U.S.C. $\S 13$ (1970).

${ }^{190} \mathrm{Cf}$. text iccompanying notes 29-32 supra.

$191^{-A}$ list of other exceptions is given in proposed rules 1101(d)-(e), 56 F.R.D. 347-48.

192 This exception was suggested by Judge Henry Friendly in commenting on this Article. See also Hearings, supra note 1, at 220.

${ }_{193}$ As noted in Section V supra, the more "substantive" the rule, the more likely it is to have been fully considered in advance of trial. 
as the traditional power of a federal judge to comment to the jury on the evidence. ${ }^{194}$ Yet the kinds of exceptions necessary are probably capable, like those currently endured, ${ }^{195}$ of sufficiently clear enumeration to avoid important difficulty. ${ }^{196}$

The kinds of functional problems pointed out in the preceding sections do not necessarily arise in connection with evidentiary "housekeeping" rules which may be more in the nature of simply procedural rules, such as rules prescribing order of witnesses, scope of interrogation and offers of proof upon an exclusionary ruling. Nevertheless, since such matters do not seem to involve important national policies, for simplicity's sake it should be urged that any federal choice-of-law evidentiary rule be broad enough to take these matters in; indeed, to take in whatever has been covered in the proposed Federal Rules of Evidence, subject to those few exceptions already noted involving important federal policies.

It is not necessary to argue at great length that Congress has power to adopt such a choice-of-evidentiary-law rule for federal courts. That power must be subsumed under its power to promulgate actual evidentiary rules for the federal courts. Moreover, the question whether there is national power would have none of the impact it has had with respect to the proposed Federal Rules of Evidence, under Erie, since what is being mandated is reference to state law. Finally, abundant precedent exists on the point that federal choice-of-law rules may be created for federal courts. ${ }^{197}$

\section{Conclusion}

The foregoing analyses indicate that the existence of national power cannot alone justify its implementation. It has been

${ }^{194}$ See authorities cited note 64 supra.

195 The current federal statutes regulating the admission of particular kinds of evidence are few in number. See generally 2B W. Barron \& A. Hogtzorf, Federal Practice and Procedure \$ 967 (Wright ed. 1958); J. Moore, Federal Practice III 44.01[4] to -.05 (2d ed. 1971). The most significant of these is the Federal Business Records Act, 28 U.S.C. $\$ 1732$ (1970). Conforming amendments to these measures were submitted to Congress by the Supreme Court along with the proposed rules. Under the suggested choice-of-law rule, these measures could-be retained or repealed.

${ }_{196}$ See Leach, supra note 47 , at $584-85$.

197 For example, FED. R. Civ. P. 43(a), as well as numerous other rules of civil procedure taking similar positions, e.g., FED. R. CIv. P. 4(e), 17(b), 62(f), 64, 69(a). Additionally, Erie and its progeny are familiar examples of vertical choice-of-law rules on both substantive and procedural questions, for the guidance of federal courts. The horizontal choice of the law of a particular state-in the suggested evidentiary legislation to be fixed as that of the forum state-has also been addressed by the Supreme Court on occasion, see, e.g., Klaxon Co. v. Stentor Elec. Mfg. Co., 313 U.S. 487 (1941), and the Court has in this way reviewed congressional legislative horizontal choices. Compare Richards v. United States, 369 U.S. 1 (1962), with Federal Tort Claims Act, 28 U.S.C. $\S 2674$ (1970). See also Death on the High Seas Act, 46 U.S.C. $\S 761$ (1970). 
a fundamental conceptual error to limit the vertical choice-of-law question to Erie and its progeny. Our federal system rests on other strong "cornerstones" as well, including the important principle that new federal law is not created in the absence of demonstrable national need. By including in our analysis the questions whether such national need exists, and, if so, whether it can be satisfied without disturbance to settled local arrangements, we are able to reach functional questions about the advantages and disadvantages of proposed new federal law, which we could not reach through traditional Erie analysis alone.

The national interest in modernization of federal evidentiary practice and in improvement of procedure in all courts is a real one. But scrutiny of the proposed Federal Rules of Evidence, in the light of functional considerations rather than with respect to their scholarly merit, indicates that no such modernization or simplification of evidentiary law has been achieved sufficient to meet the described need. Indeed, scrutiny of the proposed rules indicates that the existence of these detailed rules side by side with perhaps equally complex state rules may create undue difficulties of assimilation and application in both state and federal courts. Rather paradoxically, in light of our understandings under Erie, it may further be concluded that in inherently arbitrary areas, in which any of a number of possible rules might be a fair one, promulgation of new federal law would be particularly undesirable. That is, in this prudential area beyond the scope of Erie, the less "substantive" the content of a rule, the more it may appear that the introduction of new federal law paralleling preexisting state law would be an inappropriate exercise of the national lawmaking power.

The genuine need for unification of evidentiary rules over all headings of federal jurisdiction might therefore better be served by legislation requiring reference to forum state evidentiary law for all federal jurisdictional headings, subject to limited classes of exceptions. Such a solution may in time give way to a truly simplified scheme of evidentiary law for federal courts sufficient to serve as a model for reform of state evidentiary law.

For historic and institutional reasons, the questions this Article has raised are now exclusively for Congress. It is urged that Congress should, based upon these considerations as well as those upon which it has already acted, disapprove the promulgation of the proposed Federal Rules of Evidence. ${ }^{198} \mathrm{It}$ is

${ }^{198}$ The writer was gratified to read the testimony of Judge Henry Friendly, Hearings, supra note 1 , at $246-61$, reaching substantially similar conclusions. 
further suggested that Congress proceed to study the advisability of legislation unifying the reception of evidence under all headings of federal jurisdiction by mandating federal court reference to forum state evidentiary law. 